This PDF is a selection from an out-of-print volume from the National Bureau of Economic Research

Volume Title: Capital Flows and the Emerging Economies: Theory, Evidence, and Controversies

Volume Author/Editor: Sebastian Edwards, editor

Volume Publisher: University of Chicago Press

Volume ISBN: 0-226-18470-6

Volume URL: http://www.nber.org/books/edwa00-1

Conference Date: February 20-21, 1998

Publication Date: January 2000

Chapter Title: Capital Flows to Central and Eastern Europe and the Former Soviet Union

Chapter Authors: Stijn Claessens, Daniel Oks, Rossana Polastri

Chapter URL: http://www.nber.org/chapters/c6171

Chapter pages in book: (p. 299 - 339) 


\section{Capital Flows to Central and \\ Eastern Europe and the \\ Former Soviet Union}

Stijn Claessens, Daniel Oks, and Rossana Polastri

\subsection{Introduction and Background}

Capital flows to Central and Eastern Europe (CEE) and the former Soviet Union (FSU) represent a relatively small, albeit growing, share of capital flows to developing countries. Taking all flows together, total net flows to these twenty-five countries were about \$44 billion in 1996 (and a preliminary figure of $\$ 57$ billion for 1997), ${ }^{1}$ or about one-eighth of aggregate net flows to all developing countries. These countries accounted, however, for about 20 and 22 percent, respectively, of all developing countries' gross domestic product (GDP) and exports in 1996. As a fraction of their GDP, total inflows were consequently smaller than for many other developing countries, and averaged about 5.4 percent over the 1990-96 period. Taking debt service and capital flight into account, resource inflows were much lower and even negative to some countries (capital flight from Russia alone has been estimated at some $\$ 50$ billion for 1992-96).

The lower level of capital flows to these countries occurred during a period when global capital flows were very buoyant. Private capital flows to developing countries increased dramatically during the 1990 s, especially foreign direct investment (FDI) and portfolio equity investment.

Stijn Claessens is a lead economist in the Financial Sector Strategy and Policy Group at the World Bank. Daniel Oks is manager of the economic analysis department of the Central Bank of Argentina. Rossana Polastri is an economist in the Europe and Central Asia Region at the World Bank.

The authors thank their discussant, Michael Dooley, other participants in the preconference and conference, Ricardo Martin, Frank Lysy, Marcelo Selowsky, and participants in a World Bank workshop for useful comments. The views expressed in this paper are those of the authors and do not necessarily represent those of the World Bank.

1. Excluding grants, the total amount of net flows amounted to US\$41 billion in 1996. 
While flows to CEE and FSU have also been growing fast-for example, portfolio and FDI flows increased from $\$ 1.4$ billion in 1990 to $\$ 23.5$ billion in 1996 - between them they still attracted only about 15 percent of total private capital flows to all developing countries in $1996 .{ }^{2}$ In 1996, FDI to CEE and FSU, for example, was only $\$ 14$ billion, equivalent to the total amount received by Malaysia and Mexico in that year. The distribution of FDI flows has also been highly uneven. Over the 1992-96 period, Russia and the Visegrad countries (the Czech Republic, the Slovak Republic, Poland, and Hungary) received the bulk of FDI flows, while many other countries in the region are still all but untouched by FDI.

The still relatively low level of capital flows, especially of private capital, reflects the special nature of the economic development processes in these countries. Several factors are important. First, CEE and FSU are all transition economies. This means, for one thing, that market reforms did not get underway until the end of the 1980s for most of CEE-with the notable exceptions of Hungary and Poland-and until 1991 for the FSU. The transition process also influenced the nature and composition of the capital flows. In particular, early on in the transition the capital flows were mainly fiscally driven and often from official sources. Annual net flows of official development finance - including official development assistance (grants and official concessional loans) and official nonconcessional loans-represented about 40 percent of total net flows in 1990-96 and over 100 percent in 1990-91 (as private net flows were negative in those years). This reflected the sharp deterioration of fiscal revenues at the onset of the transition process and the lack of credit worthiness of some countries. Associated with this process were low private capital inflows, and, as mentioned, for some countries substantial amounts of capital flight. The low level of private inflows was due to a variety of factors, including partial and incomplete reforms or an uncertain commitment to reform in most countries, high political and social costs of the transition process itself, and high levels of corruption and political instability (several countries in the FSU have been affected by civil wars). Many countries in CEE also lost financing and aid from the Soviet Union-they had received a large amount of aid, including above-market export prices and below-market import (especially energy) prices, from the Soviet Union (World Bank 1992), but these flows essentially ceased in 1989-implying a larger financing need for their governments.

In more recent years, there has been a more rapid inflow of private capital, as reform efforts have consolidated and economic prospects improved and, for some countries, as European Union (EU) integration became a possibility for the near future. For some countries, short-term capital has recently become an important source of external financing. Since

2. Portfolio and FDI flows to all developing countries in 1996 were $\$ 155$ billion. 
most countries have been "latecomers" to the phenomenon of large private capital inflows, they have not experienced much of the overheating phenomena that have affected other developing countries in the past (Latin America) and recently (East Asia). The main exceptions, indeed, were precisely some of the earlier and faster reformers like Hungary, Poland, the Czech Republic, and Estonia.

At the same time, the transition to a market economy is far from complete for most of the economies in the region. Distortions in factor markets are still prevalent and the institutional development in areas crucial to beneficial financial integration-particularly the legal system and financial sector -is still limited, especially in many of countries of the FSU. Deficiencies, which in other developing countries have been associated with subsequent problems, including poor resource allocation and financial crises, are thus still prevalent in many transition economies. By tackling these issues now, these countries could presumably stand to gain more of the benefits and to run less of the risks associated with more financial integration and large private capital flows.

This paper investigates the amounts, types and sources of capital flows to these countries. It tries to determine the motivation of the various sources of capital flows, distinguishing global and country-specific factors. The paper provides estimates of the (econometric) relationships between, on one hand, the different kinds of capital flows and, on the other hand, the reform process, macroeconomic fundamentals and performance, and external factors. Because the history of capital flows to CEE and FSU is short, historical analysis has significant limitations and econometric estimation is difficult. Lessons from experiences of other countries with private capital flows may, however, be applied to these countries, when taking into account their special characteristics.

The paper is organized as follows. Section 9.2 briefly describes the facts about capital flows to these countries. Section 9.3 discusses important links and relationships between macroeconomic variables and the capital flows, including some of the basic motivations and causes for capital flows. Section 9.4 describes and analyzes the policy framework and policy responses in those countries that received the bulk of capital flows. Econometric tests are presented in section 9.5, while section 9.6 discusses the issues surrounding capital flows that may in the future arise in these countries, and provides some conclusions.

\subsection{Facts about Capital Flows to Central and Eastern Europe and the Former Soviet Union}

We start by providing some simple raw statistics for the various capital flows. In principle, one can distinguish capital flows by destination (e.g., public versus private); by type (e.g., long-term and short-term debt, FDI, 
bonds and equity portfolios); and by origin (e.g., commercial, that is private, versus official creditors). One can also combine the three distinctions, for example, by splitting debt-type flows into public and private debt, with the latter further into long and short, and by origin, for example, commercial versus official. For our purposes, and given the data we have at hand and the patterns in capital flows we observe, we create five categories of capital flows: public debt (official) flows; commercial long-term (LT) debt flows; commercial short-term (ST) debt flows; FDI flows; and portfolio (bond and equity) flows. For some purposes, it would be useful to further split commercial debt flows into those going to the banking system and those going to other sectors of the economy, but it turns out that this cannot be done for most of the countries given the data available. Our focus is on net flows; however, while we occasionally also discuss "capital flight" (other than that captured through short-term flows), we do not net out capital flight from our net flow measures. We group countries in two regions: (1) Central Europe and the Baltics, and (2) the rest of Eastern Europe, the Caucasus, and Central Asia. ${ }^{3}$ The group of countries in Central Europe is relatively homogeneous. The countries in the second regional group have more diverse economic characteristics. ${ }^{4}$

Descriptive statistics for the different types of flows for all countries (means, medians, standard deviations of flows) are provided in table 9.1. Table 9.2 describes the composition of capital flows by source (private and official) and by type (long-term, short-term, portfolio, and FDI). Total capital flows rose from around \$1 billion in 1990 to \$57 billion in 1997. Pooling together all observations (by country and by year) and measuring them as a share of GDP, the largest types of flows during the 1992-96 period were official debt flows and FDI (on average, respectively, 2.7 percent and 2 percent of GDP), followed by portfolio flows ( 0.4 percent of GDP). Of all these flows, the highest standard deviation was for official flows (standard deviation of 3.6 percent of GDP). The following other stylized facts can be observed. ${ }^{5}$

First, the share of official flows has declined sharply over the period (fig. 9.1). At the beginning of the transition, official flows increased sharply, with bilateral and multilateral sources accounting for most of the flows. In 1992 , as some of the transition economies regained access to international credit markets, private flows began to exceed official flows and by 1997

3. The CEE and Baltics country group includes Albania, Bulgaria, Croatia, the Czech Republic, Estonia, Latvia, Lithuania, FYR Macedonia, Hungary, Poland, Romania, Slovakia, and Slovenia. The FSU country group includes Armenia, Azerbaijan, Belarus, Georgia, Kazakhstan, the Kyrgyz Republic, Moldova, Russia, Tajikistan, Turkmenistan, and Ukraine.

4. We had to be careful for the exchange rate used in calculating dollar GDP given the large changes in real exchange rate for this period. Some smoothing was necessary, which was done using the World Bank Atlas \$-GDP figures.

5. Sobol (1996) also highlights the rapid surge in private capital flows to CEE. 
Table 9.1

Capital Flows to CEE and FSU Countries: Descriptive Statistics (percentage of GDP per year)

\begin{tabular}{|c|c|c|c|c|c|c|c|}
\hline & $\begin{array}{l}\text { Total } \\
\text { Capital }\end{array}$ & $\begin{array}{l}\text { Private } \\
\text { Capital }\end{array}$ & $\begin{array}{l}\text { Official } \\
\text { Capital }\end{array}$ & FDI & Portfolio & $\begin{array}{c}\text { Commercial } \\
\text { Debt }\end{array}$ & $\begin{array}{c}\text { Short-Term } \\
\text { Debt }\end{array}$ \\
\hline Mean & 5.92 & 3.22 & 2.70 & 1.98 & 0.41 & 0.85 & 0.56 \\
\hline Median & 4.89 & 2.11 & 1.78 & 1.03 & 0.00 & 0.18 & 0.12 \\
\hline Maximum & 21.02 & 17.48 & 15.04 & 17.48 & 10.15 & 10.92 & 13.10 \\
\hline Minimum & -3.12 & -1.95 & -2.98 & 0.00 & -3.33 & -2.98 & -10.67 \\
\hline Standard deviation & 4.84 & 3.73 & 3.57 & 2.61 & 1.66 & 1.89 & 2.49 \\
\hline
\end{tabular}




\begin{tabular}{|c|c|c|c|c|c|c|c|c|}
\hline & 1990 & 1991 & 1992 & 1993 & 1994 & 1995 & 1996 & 1997 \\
\hline \multicolumn{9}{|c|}{ Central Europe, Baltics, and FSU } \\
\hline \multicolumn{9}{|l|}{ By source } \\
\hline Private flows & $-4,047$ & 4,700 & 13,231 & 18,939 & 14,693 & 31,231 & 32,930 & 41,748 \\
\hline Official flows & 4,946 & 13,237 & 10,423 & 10,001 & 10,914 & 12,578 & 11,440 & 15,587 \\
\hline \multicolumn{9}{|c|}{ Grants (excluding technical } \\
\hline cooperation) & 640 & 3,924 & 4,718 & 3,683 & 4,895 & 5,217 & 2,479 & 4,269 \\
\hline IMF & 328 & 3,641 & 1,836 & 2,045 & 2,352 & 4,745 & 3,325 & 3,400 \\
\hline \multicolumn{9}{|l|}{ By type $e^{\mathrm{a}}$} \\
\hline Long-term debt flows & 10,011 & 6,863 & 12,932 & 11,528 & 5,481 & 9,269 & 12,351 & 20,030 \\
\hline Short-term debt flows & $-11,181$ & -262 & -104 & -107 & 2,720 & 3,106 & 2,522 & 3,480 \\
\hline Foreign direct investment & 300 & 2,246 & 3,237 & 5,696 & 6,406 & 16,116 & 14,440 & 14,939 \\
\hline Portfolio & 1,071 & 1,422 & 1,047 & 6,194 & 3,756 & 5,177 & 9,144 & 8,890 \\
\hline \multicolumn{9}{|c|}{ Central Europe and Baltics } \\
\hline \multicolumn{9}{|l|}{ By source } \\
\hline Private flows & 749 & 4,179 & 2,538 & 16,018 & 12,448 & 28,072 & 21,111 & \\
\hline Official flows & 585 & 5,259 & 4,191 & 3,181 & 4,223 & 4,665 & 2,600 & \\
\hline \multicolumn{9}{|c|}{ Grants (excluding technical } \\
\hline cooperation) & 40 & 3,380 & 2,116 & 1,477 & 2,386 & 3,749 & 1,404 & \\
\hline IMF & 328 & 3,641 & 823 & 206 & 107 & $-2,723$ & -795 & \\
\hline
\end{tabular}




\begin{tabular}{|c|c|c|c|c|c|c|c|}
\hline By type & 1,893 & 9,291 & 5,448 & 18,026 & 14,393 & 26,085 & 21,513 \\
\hline Long-term debt flows & 974.1 & 2,541 & $1,215.6$ & 6,027 & 3,588 & 8,131 & 6,909 \\
\hline Short-term debt flows & -780.5 & -761.9 & $-1,144.2$ & 379 & 2,201 & 3,483 & 2,272 \\
\hline Foreign direct investment & 300 & 2,449 & 3,507 & 5,220 & 4,978 & 11,874 & 9,370 \\
\hline \multirow[t]{2}{*}{ Portfolio } & 1,071 & 1,422 & 1,047 & 6,194 & 3,519 & 5,321 & 3,757 \\
\hline & \multicolumn{5}{|c|}{ Former Soviet Union } & & \\
\hline \multicolumn{8}{|l|}{ By source } \\
\hline Private flows & $-4,796$ & 521 & 10,693 & 2,921 & 2,245 & 3,159 & 11,818 \\
\hline Official flows & 4,361 & 7,978 & 6,232 & 6,820 & 6,691 & 7,913 & 8,840 \\
\hline \multicolumn{8}{|c|}{ Grants (excluding technical } \\
\hline cooperation) & 600 & 544 & 2,602 & 2,206 & 2,509 & 1,468 & 1,075 \\
\hline IMF & 0 & 0 & 1,013 & 1,839 & 2,245 & 7,468 & 4,120 \\
\hline By type & $-1,363$ & 4,619 & 13,500 & 7,329 & 6,321 & 12,328 & 20,269 \\
\hline Long-term debt flows & 9,037 & 4,322 & 11,716 & 5,501 & 1,893 & 1,138 & 5,442 \\
\hline Short-term debt flows & $-10,400$ & 500 & 1,040 & -486 & 518 & -377 & 250 \\
\hline Foreign direct investment & 0 & -203 & -269 & 475 & 1,428 & 4,242 & 5,070 \\
\hline Portfolio & 0 & 0 & 0 & 0 & 237 & -143 & 5,387 \\
\hline
\end{tabular}

Source: Global Financial Development, World Bank 1998. Data for 1997 are preliminary and are only available for the whole region. "Excluding IMF, grants, and technical cooperation. 


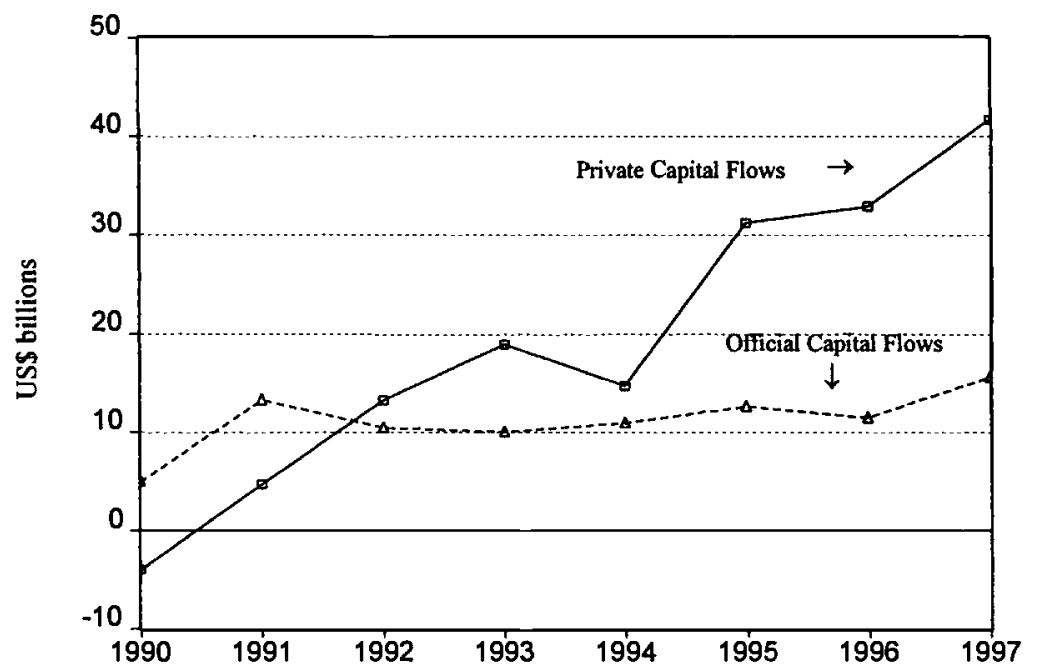

Fig. 9.1 Official versus private capital flows, CEE and FSU countries

they accounted for 73 percent of total flows. This development is not different from what has been observed in other developing countries, but in these transition economies the change in composition appears to have occurred more swiftly. The reduced reliance on official flows has been more marked in Central Europe and the Baltics than in the FSU. While FDI and portfolio flows were already large in Central Europe and the Baltics in 1991-92, they only acquired significance in the FSU after 1994. This is consistent with the onset of earlier reforms and improved access to international capital markets of Central Europe and the Baltics.

Second, there has been a rapid surge of short-term capital flows (shortterm debt plus portfolio flows) from about $\$ 1$ billion in 1991-92 to \$20 billion in 1996-97-with the share in total flows increasing from 5 percent to about one-quarter (fig. 9.2). The surge in short-term flows could be a source of concern for policy makers, as short-term flows could be associated with higher volatility. This may be especially so for those countries that received the bulk of short-term flows: During 1993-96, the largest recipients were Hungary, the Czech Republic, Russia, Slovakia, Ukraine, and Slovenia, with these countries in total receiving over 90 percent of all short-term flows.

Third, the destination of private capital flows has been heavily concentrated. ${ }^{6}$ A few countries - Russia, Hungary, Poland, and the Czech Re-

6. Defined as the sum of FDI, portfolio flows, commercial debt flows, and short-term flows. 


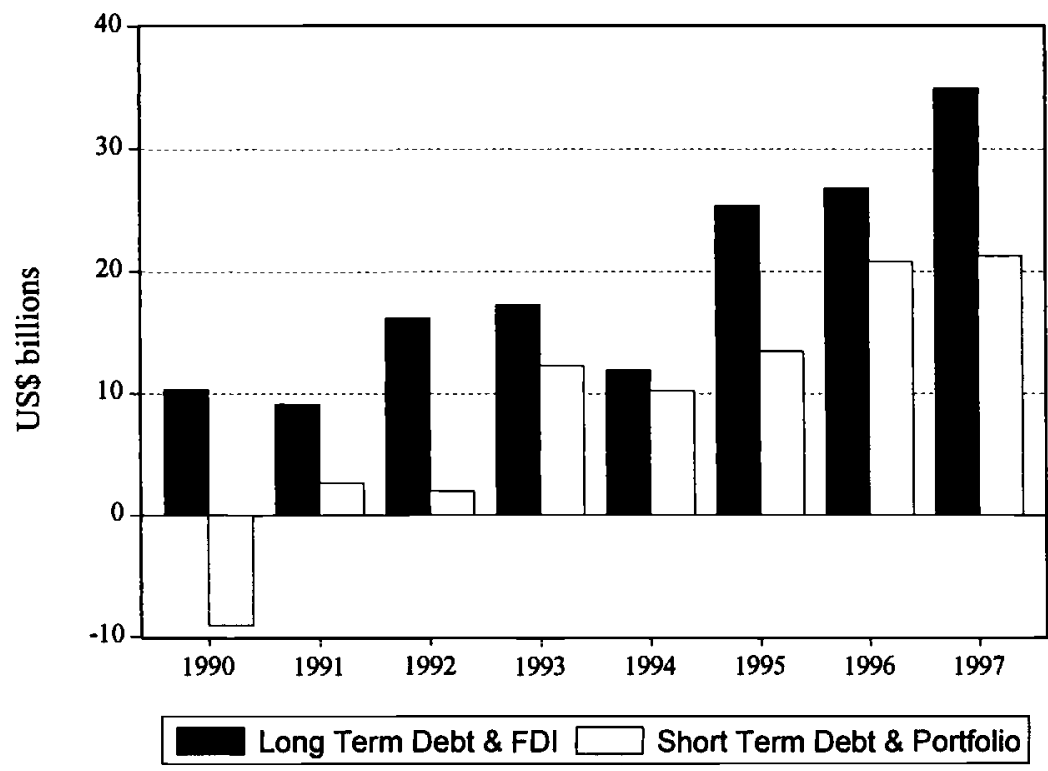

Fig. 9.2 Long-term and short-term capital flows, CEE and FSU countries

public - together accounted for about 80 percent of private capital flows to the region (fig. 9.3). The above four countries, along with a second group of countries - Romania, Kazakhstan, Ukraine, Slovenia, Slovakia, Lithuania, Estonia, and Croatia-accounted for about 98 percent of all private capital 'flows to the region. The concentration for FDI was even higher. Two countries, Poland and Hungary, for example, received over 50 percent of the 1992-96 cumulative FDI to the region ( $\$ 46$ billion).

Fourth, official capital flows-excluding flows from the International Monetary Fund (IMF) - have also been heavily concentrated, although mostly in a different set of countries than private flows. On a cumulative basis during 1992-96, five countries (Romania, Russia, Kazakhstan, Ukraine, and Bulgaria) received over 75 percent of all official flows (fig. 9.4). Some of the earlier recipients of official flows subsequently repaid large amounts of official debt and, thus, on a net cumulative basis, the significance of official financing for these countries is somewhat understated. Russia and Poland, for example, received around $\$ 2.4$ billion in official financing in 1993-94 and repaid over \$3 billion in 1996.

\subsection{Linkages between Macroeconomic Variables and Capital Flows}

We start with a description of some of the initial conditions that played an important role in determining the nature and type of capital inflows. 


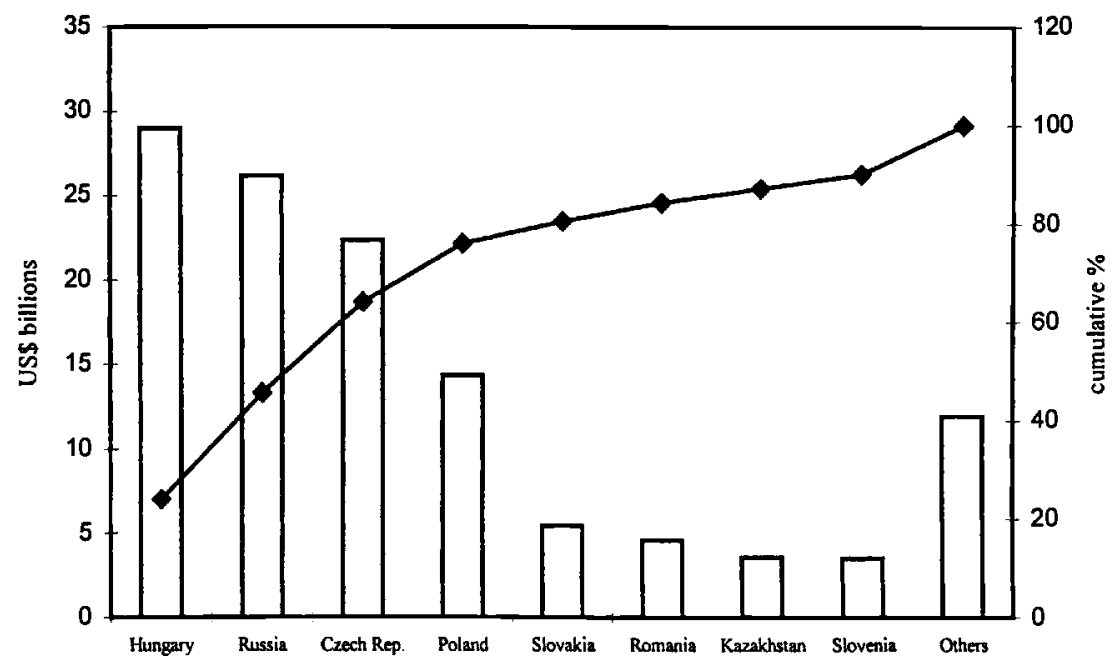

Fig. 9.3 Major recipients of private capital flows, 1990-96

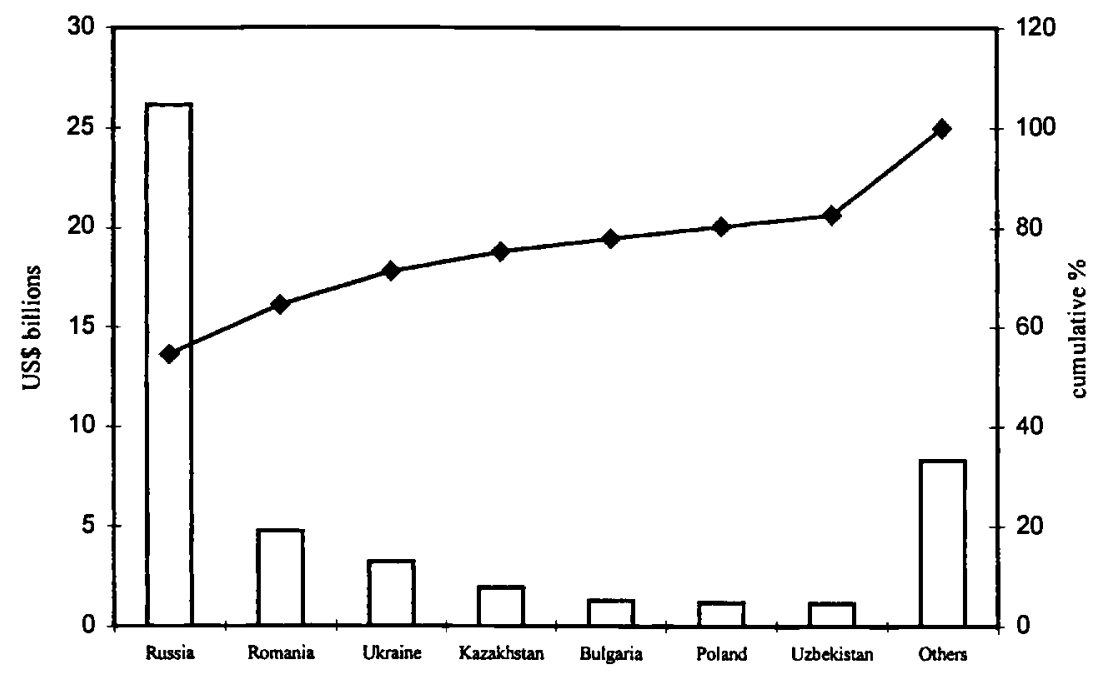

Fig. 9.4 Major recipients of official capital, 1990-96

The underlying factors behind private flows are quite different from those underlying official flows. In the case of private flows, credit worthinessas a result of structural reforms and strong macroeconomic fundamentals - and economic and financial opportunities-such as high interest rate differentials - tend to drive flows. In the case of official flows, political considerations (including geopolitical or social stability), commitment to reforms (usually reflected in the conditions applied to official financing), 
and the fiscal deficit tend to be important determinants. We therefore discuss private and official flows separately.

\subsubsection{Private Flows}

Private capital flows depend on domestic factors and international factors, such as foreign interest rates or demand conditions abroad (see Calvo, Leiderman, and Reinhart 1993). In turn, domestic factors can be broadly classified into structural reforms (e.g., openness, privatization, financial sector deepening, banking sector stability), credit worthiness and macroeconomic fundamentals (e.g., fiscal deficit, debt to GDP ratio, ratio of short-term debt or monetary base to foreign reserves), private sector behavior (e.g., propensity to save), economic performance indicators (e.g., GDP growth), and arbitrage opportunities (e.g., domestic-foreign interest rate differentials adjusted for expected devaluation). As we discuss below, different types of private flows are likely to depend differently on specific subsets of these explanatory variables.

The importance of credit worthiness is well illustrated by the experiences of Poland and Hungary. Poland started the transition period with a large commercial debt stock, the result of heavy borrowing during the early 1980s in an attempt to maintain domestic consumption and government expenditures. As this borrowing occurred under the "umbrella" of the then Soviet Union, Poland's individual credit worthiness mattered less. The subsequent political transition and loss of the umbrella resulted, however, in a rapid loss of credit worthiness in the late 1980s. Poland subsequently had to go through first a Paris and then a Brady plan debt reduction and debt relief program to bring its debt back to sustainable levels. It took until October 1994 before the Brady debt reduction plan was completed and only afterward did private capital flows take off.

Bulgaria also had to go through a debt reduction and rescheduling operation after it incurred large amounts of hard currency debt in the late 1980s when aid from the Soviet Union was sharply reduced. Following Bulgaria's Brady debt agreement, private capital flows became positive for the first time since the onset of transition, and particularly after the country adopted a currency board in mid-1997. It appears that the currency board provided an implicit exchange rate insurance that, combined with a high interest rate differential and increased credit worthiness (through both debt reduction and lengthening of the maturities of external debt), attracted private capital flows.

In the case of Hungary, the initial debt stock was also high, but Hungary did not resort to debt rescheduling or reduction. This signaled Hungary's commitment to servicing its international obligations in full and on time; that, in turn, may have bolstered other kinds of private inflows. Until 1995, Hungary was the largest recipient of private capital flows in the region. However, Hungary relied mostly on FDI and portfolio flows for its financ- 
ing needs as commercial lenders were reluctant to extend large amounts of new financing (in part this was also due to problems with the provision of accurate balance-of-payment information during the 1980s).

Initially, Russia was in a somewhat better position than most countries as its outstanding debt obligations were relatively low. But large borrowings during the late 1980s, much of it from official sources, led to subsequent debt servicing problems, which were partly resolved through repeated reschedulings. Nevertheless, debt stocks and debt service remained and remain high relative to exports and GDP (it should be noted, however, that Russia has run consistently large trade surpluses). In the case of Russia, what led to large private inflows was probably not so much (the perception of) improved credit worthiness, but rather the very high interest rates on government bonds. In 1996, Russia received $\$ 7.3$ billion in portfolio flows, most of it to finance the government deficit.

For the rest of the FSU, inherited debt stocks were zero as they all reached agreement in the early 1990s for Russia to assume all debts and assets of the FSU (as the states of the FSU had each signed a joint and several liability agreement for the external debt, assumption of claims was necessary and the only practical solution). This "zero debt" initial condition was a factor in why early reformers - like most of the Baltics - were able to attract substantial private flows from the outset, almost $\$ 3$ billion over the $1992-96$ period.

Non-debt-creating private flows to the region, including FDI, were low until 1990 (less than half a billion dollars annually) with, as noted, most of it going to Hungary. The transition to market economies created opportunities for foreigners to engage in long-term risk investments in the region. But even though FDI grew, from $\$ 2.2$ billion in 1991 to $\$ 6.4$ billion in 1994, it remained small relative to other regions. In 1994, for example, it was less than FDI to Mexico in that year. As reform in these countries further progressed, FDI rose significantly, reaching \$16.1 billion in 1995although this figure is somewhat distorted by record-high privatizationrelated FDI in Hungary ( $\$ 4.5$ billion in 1995). ${ }^{7}$ This reflected in part a general increase in FDI to developing countries. But there also appears to have been a threshold effect such that, once reform passed a certain level, a takeoff of private capital flows in general occurred (fig. 9.5).

Domestic reforms aimed at liberalizing prices, trade, and private sector activities have been very important for motivating the inflow of private capital. Countries did pursue many policies to attract capital flows, in particular they quite rapidly liberalized their current and capital accounts. In addition, some provided official guarantees for flows to private borrowers, while others provided special tariff or tax regimes to attract FDI flows. Compared to the impact of general reform, however, specific policies appear to have played a limited role in explaining capital flows. 


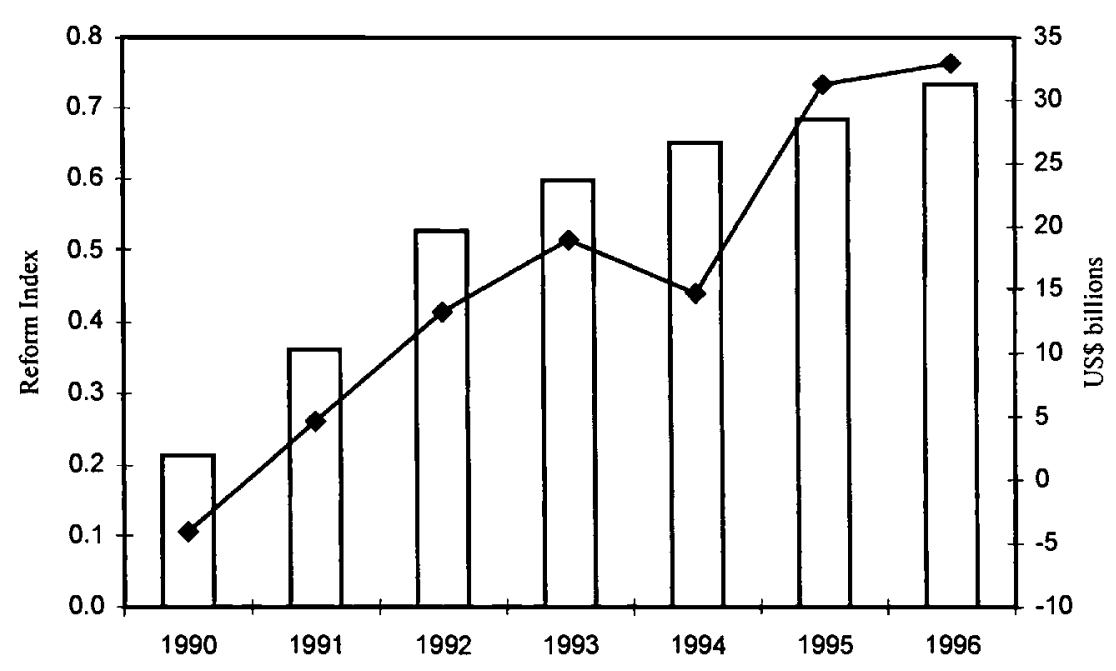

Fig. 9.5 Net private capital flows (line) and reform efforts (columns)

Some countries experienced large private capital inflows to private companies and state enterprises early on, even prior to the transition, but this most often reflected special circumstances. Several countries are well endowed with natural resources and were as a result able to attract FDI in these sectors, even when overall market reforms were still at an early stage. About half of total net inflows for Azerbaijan and Kazakhstan in 1995 and 1996, for example, were in the form of FDI, even though they scored low on policy reform. In other countries, the privatization strategy that was pursued greatly influenced capital flows (fig. 9.6). For example, since the onset of transition, Estonia, and Hungary even earlier, pursued a policy of actively selling firms on a case-by-case basis to strategic investors, including foreign investors. As a result, FDI inflows dominate private inflows for both countries (FDI inflows to Hungary actually exceeded in 1996 total net flows). And in the case of Russia in recent years, FDI flows have increased significantly as a result of the privatization of a few large resource-based state enterprises.

Capital flows have also been influenced by the behavior of domestic savings. Theoretically, foreign savings can be a complement to or a substitute for private domestic savings. The type of relationship between capital flows and domestic savings can have a bearing on the sustainability of capital flows. Hernandez and Rudolph (1995) found for economies in other regions that capital flows tend to be more sustainable when foreign and domestic savings are complementary. Figure 9.7 suggests a complementarity between aggregate domestic savings and total private flows. Based on this complementarity alone, capital flows are likely to be sustainable.

A few countries have had (temporary) situations of "overheating" associated with large private capital inflows (excluding FDI). For example, 


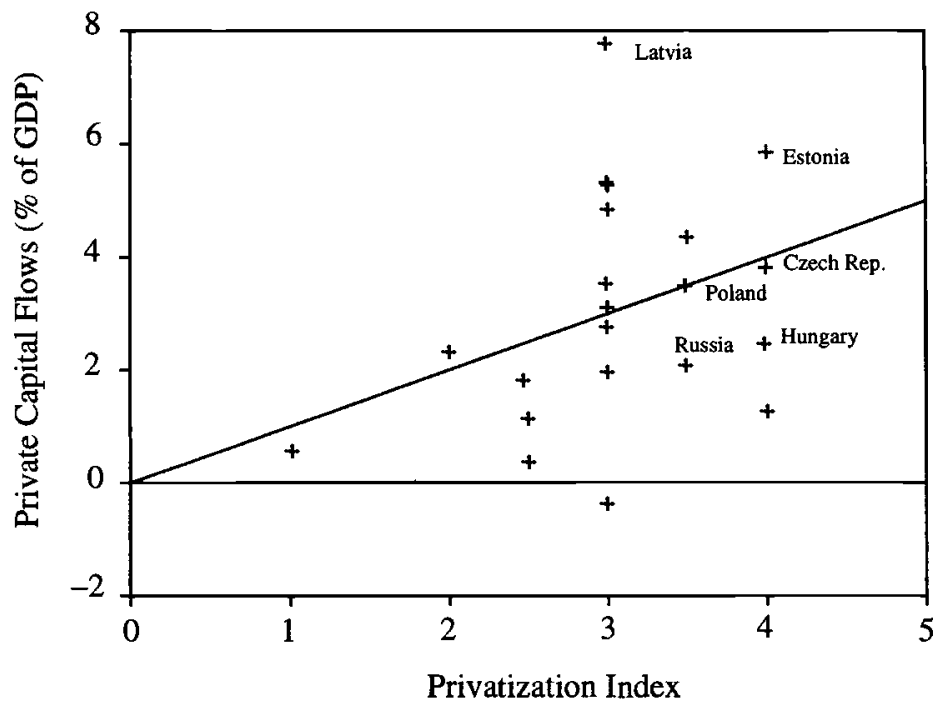

Fig. 9.6 Net private capital flows versus privatization progress, 1992-96 Note: Privatization index is obtained from EBRD Transition Report.

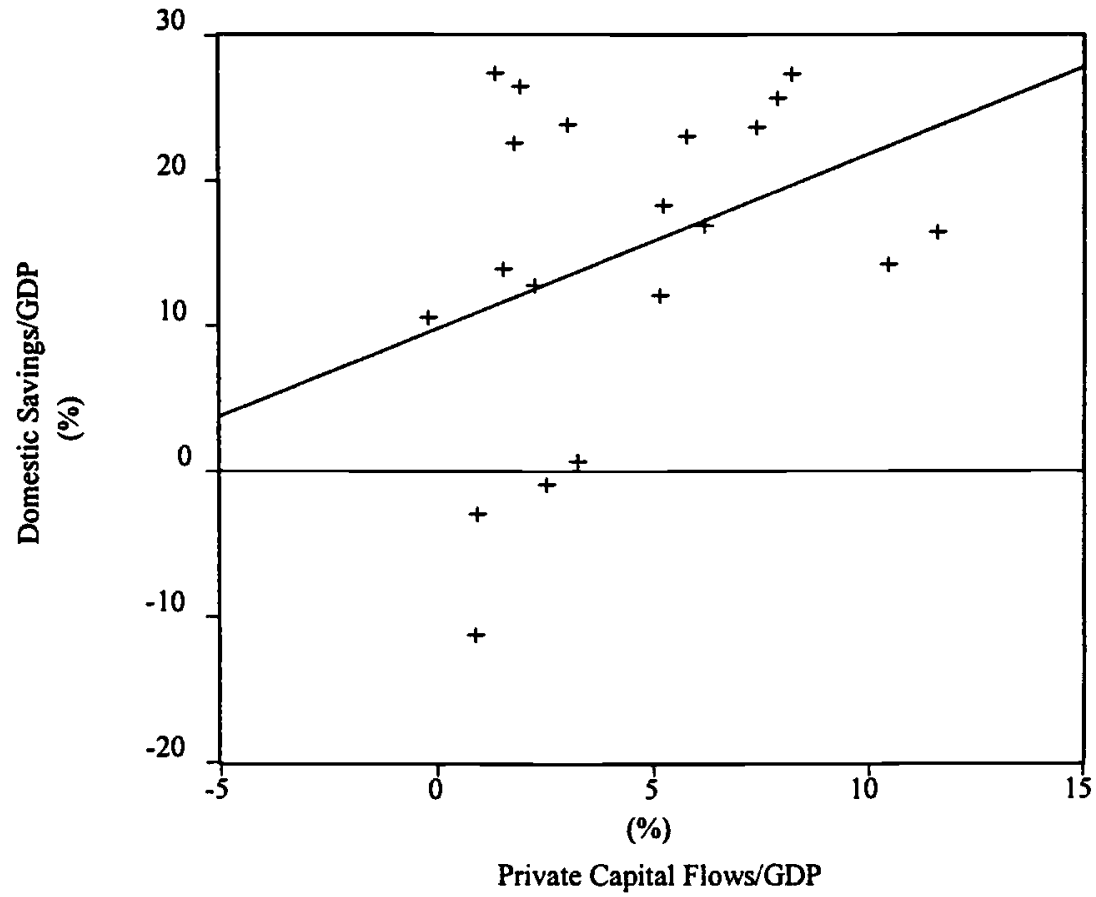

Fig. 9.7 Domestic savings and net private capital flows 
private debt flows were large in the Czech Republic and Slovakia during 1995; and portfolio flows were large in Poland and Hungary during 1995, in Russia during 1996, and in Poland during 1997. For the region as a whole, however, short-term private flows (excluding FDI) were insignificant before 1993 and were less than one-third of all flows thereafter. More importantly, with a few exceptions, the share of capital flows relative to GDP remained small. Relative to GDP, only the Czech Republic and Hungary received in 1995 large amounts of private capital flows-10.9 percent and 8.2 percent, respectively. So did some of the smaller FSU countries in some specific years, but this mainly reflected the lumpy nature of private capital flows (e.g., FDI in a gold mine in the Kyrgyz Republic in 1995-96) or, in the case of some Baltics, heavy intermediation of foreign funds by local banks. Even these relatively high levels of capital inflows were well below the sustained high levels of capital inflows seen in recent years for some East Asian and Latin American countries, for those countries had several years of current account deficits up to 8 to 9 percent that were largely privately financed and, unlike in transition economies, often associated with strong declines in domestic saving (see Alba et al. 1999).

Though not for the region as a whole, there are several cases where financial arbitrage likely played a major role in motivating capital flows. For example, in recent years, there has been substantial foreign investment in portfolio flows in the form of purchases of local currency fixed-income instruments, such as Russian, Polish, Hungarian, and Czech treasury bills and treasury bonds. Table 9.3 suggests a positive link between high interest rate differentials (domestic interest rates corrected for the ex post exchange rate devaluation minus the U.S.-dollar London Inter-Bank Offering Rate [LIBOR]) and private capital inflows in these countries. For some countries, bond inflows have coincided with large and rapid equity portfolio inflows, much of it through American depositary receipts (ADRs)/ global depositary receipts (GDRs) and country funds. In the Czech Republic, for example, there were large equity inflows in 1995 when the equity market increased by 150 percent. ${ }^{8}$ Similarly, Estonian banks relied heavily on foreign issues of Eurobonds to lower their funding costs during 1996-97. As demand for paper of emerging economies in CEE grew, domestic interest rates declined. The eruption of financial turbulence in Asia led to substantial outflows and a steep rise in spreads of Eurobonds issued by these countries over comparable U.S. treasuries (as well as declines in stock markets). This was especially the case for Russia, Estonia, Poland, and the Czech Republic, but affected more or less all countries in the region. Since then, spreads have declined to close to pre-Asian crisis levels.

Figure 9.8 shows that there has been a positive association between

8. Foreign purchases of equity securities increased from $\$ 497$ million in 1994 to $\$ 1,236$ million in 1995. 


\section{Table 9.3}

Nonequity Portfolio Flows and Interest Rate Differential

\begin{tabular}{|c|c|c|c|c|c|c|c|c|c|c|c|c|c|c|c|}
\hline & \multicolumn{3}{|c|}{ Poland } & \multicolumn{3}{|c|}{ Czech Republic } & \multicolumn{3}{|c|}{ Slovak Republic } & \multicolumn{3}{|c|}{ Hungary } & \multicolumn{3}{|c|}{ Russia } \\
\hline & 1995 & 1996 & $1997^{\mathrm{a}}$ & 1994 & 1995 & 1996 & 1994 & 1995 & 1996 & 1994 & 1995 & 1996 & 1994 & 1995 & 1996 \\
\hline $\begin{array}{l}\text { Nonequity } \\
\text { portfolio (in } \\
\text { US\$ millions) }\end{array}$ & 250 & -531 & 2,200 & 733 & 1,288 & 562 & 218 & 210 & -264 & 2,124 & 1,729 & $-1,873$ & -184 & $-1,576$ & $-2,320$ \\
\hline $\begin{array}{l}\text { Interest rate } \\
\quad \text { differential }(\%)\end{array}$ & 14.4 & 7.6 & 0.2 & 8.3 & 15.6 & 6.1 & 5.5 & 19.4 & 5.1 & 6.4 & 4.7 & -2.3 & n.a. & 22.1 & 57.5 \\
\hline
\end{tabular}

"Breakup in bonds and equity flows is not available for Poland for 1997; figure reflects total portfolio investment. 

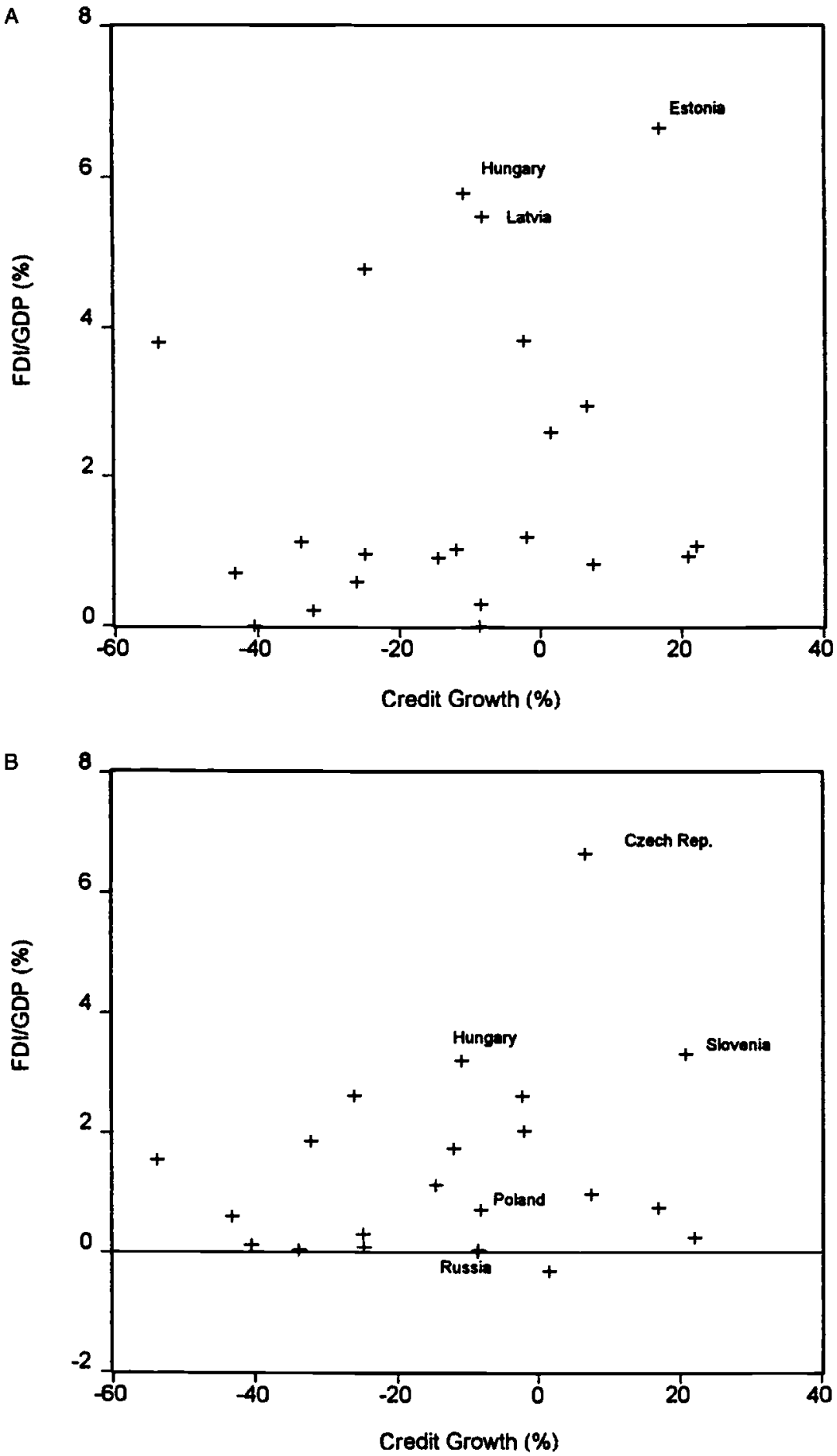

Fig. 9.8 $A$, FDI versus real credit growth; $B$, Private debt flows versus real credit growth 
domestic credit growth and private capital inflows for only a few countries. The association for these countries stems both from general equilibrium effects and from banks directly intermediating capital flows. The large credit growth often seen in other developing countries has thus been much less observed for these countries. This may be due to the early phase of the expansionary cycle for most countries or to the poor state of institutional development of the banking systems in these countries, where foreign lenders are reluctant to lend large amounts to still weak banks. Direct intermediation of foreign savings through domestic banks has, for most countries, been limited. An exception has been Estonia, where in 1997 the banking sector relied heavily on foreign issues of Eurobonds to finance their domestic lending. Because of the general equilibrium effects of capital inflows, however, there were a few other countries where high credit growth and large capital inflows coincided (e.g., the Czech Republic).

Finally, while policy variables are what matter most from the point of view of policy makers, there is evidence that capital inflows have been often associated with improvements in key macroeconomic performance indicators such as GDP growth. As figure 9.9 illustrates, private capital flows exhibit a positive relationship with GDP growth. This highly observable performance indicator may serve as a proxy, to private investors, for effective reforms.

\subsubsection{Official Flows}

In the early stages of reform in CEE and FSU, a major share of official assistance took the form of balance of payments and budgetary support, including official debt relief. This was necessary as the transition meant a substantial drop in fiscal revenues, especially for the FSU countries where government revenues essentially collapsed. Receipts from the state enterprise sector fell sharply, partly as a result of privatization, partly as a result of the elimination (or reductions) of price subsidies, and partly as a result of a breakdown of the tax system. Price liberalization brought into the open the extensive systems of cross-subsidies inherent in the planned economy, shifting all or most of the cost onto the budget. Also, the new tax administrations proved unable to tax the emerging sectors. At the same time, there were pressures to maintain expenditures, especially for social purposes.

Fiscal deficits were large in many transition economies during 1990-96, averaging 6 to 7 percent of GDP in Bulgaria, Hungary, and Uzbekistan. They were even higher in Russia - an average of 8.5 percent of GDP during 1992-96-and continued to be high in 1997. In addition, governments often mandated the banking system to undertake quasi-fiscal activitiesmost often extending (subsidized) credits to state enterprises (Claessens and Peters [1997] analyze the case of Bulgaria; Claessens and Abdelati [1996] the case of Romania). Among slower reformers, credit subsidies from the central bank were on the order of three times the size of the fiscal deficit (De Melo and Denizer 1997). Much of these fiscal and quasi-fiscal 

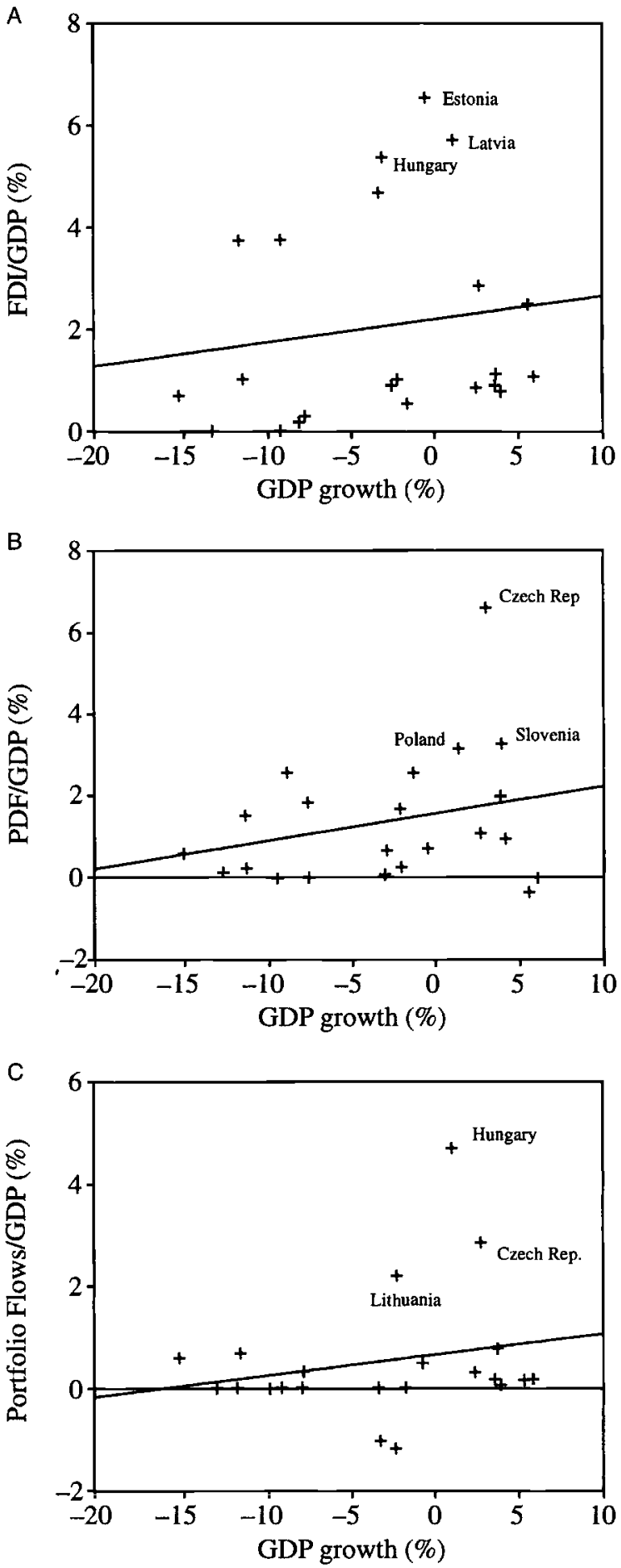

Fig. 9.9 $A$, FDI versus GDP growth; $B$, Net private debt flows versus GDP growth; $C$, Portfolio flows versus GDP growth 


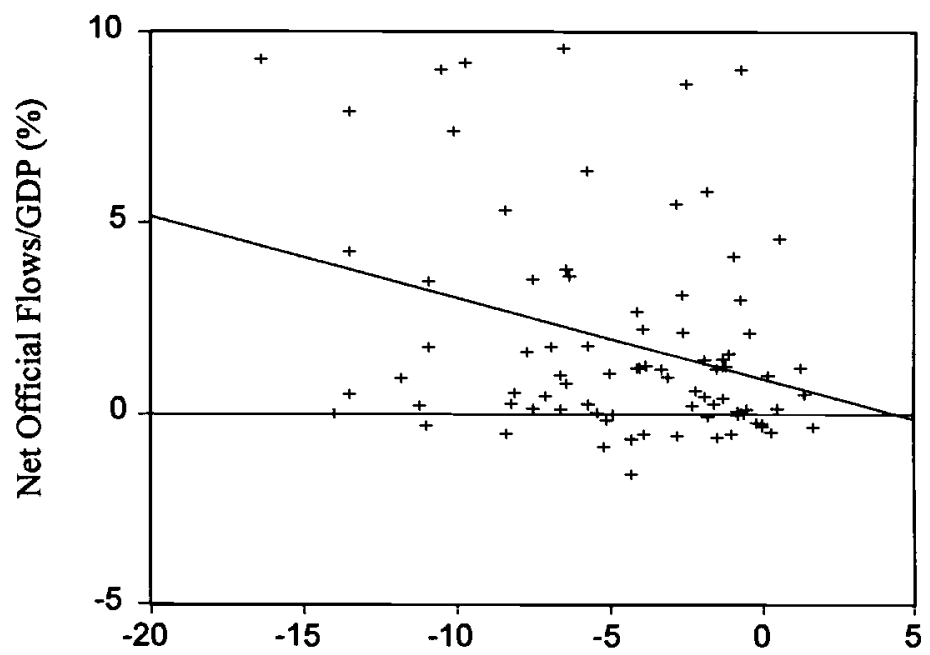

Fiscal Deficit/GDP (\%)

Fig. 9.10 Official capital flows and fiscal deficit

deficits ended up being funded through seignorage and inflation tax. Seignorage averaged more than 16 percent of GDP in Russia during 1992-93, about the same as total central government revenues (Easterly and Viera da Cunha 1994). In CEE, it was more modest, averaging 5 to 6 percent of GDP in Poland and Hungary during 1990-92. As figure 9.10 shows, offcial flows tend to have a close relationship with the fiscal deficits; the two variables indeed have one of the closest correlation relationships for all types of capital flows and various possible explanatory variables (a correlation coefficient of -0.69 , where a fiscal deficit is defined negative).

Official support (from international financial institutions and individual country donors) provided partial financing for these fiscal deficits, thus reducing inflationary pressures. Official support, however, was also conditioned on reform efforts and has typically been larger, relative to population or GDP, for those countries that subsequently advanced further with reforms. For example, the Visegrad countries, the most advanced reformers (along with the Baltics), had received by the end of 1993 more than half of all the disbursements of international financial institutions to the region. Total official disbursements to the CEE, which have generally progressed farthest in their reforms, accounted for an average of about 2.7 percent of their GDP in 1991-93, actually comparable to the Marshall Plan (aid under the Marshall Plan after World War II averaged 2.5 percent of the incomes of recipient countries during the period it was being disbursed). External official finance has thus helped underpin a number of 
reform and stabilization programs, create confidence (as was true of the Polish stabilization fund), and reduce the need for monetary financing to cover budget deficits. Bilateral and multilateral (mainly the EU) assistance has also had a large component of technical assistance.

But for sustained reformers the period of official flows was short: the Czech Republic, for example, drew on IMF credits and other official loans relatively heavily in 1991 and 1992 , but started to repay the IMF earlier than planned-as did Poland and Hungary in 1995. Similarly, Estonia maintains an IMF program but does not draw from it. This may explain why there is a negative correlation between the reform index and official flows for the whole period. A simple regression of a reform index on lagged official flows - see section 9.5-indeed suggests that official flows have exerted a positive impact on subsequent reforms. The results in section 9.5 also suggest that countries that reformed significantly over the period managed to attract higher private flows and may, thus, have experienced less need for official flows.

In 1994, official lending shifted to the FSU, which had previously obtained little official financing, as reforms advanced there. But reform strengths did differ considerably among FSU countries, and so did official flows. Among the FSU, the Baltic states, which had made substantial reforms, received more official assistance in relation to the size of their population as well as to GDP than, for example, did Belarus. Even today, many transition economies in the FSU still depend heavily on external capital flows for the financing for their fiscal deficits, with much of this financing from official sources. This is especially the case in Central Asia and some of the Caucasus countries, where official flows have been more than 5 percent of GDP for several countries. Relatively few countries have been successful in attracting private capital flows to finance their fiscal deficits. Most notable among these countries was Hungary and, in the last two years, Russia, which received some private inflows, mostly in the form of Eurobonds, for fiscal deficit financing.

In summary, official flows have been fiscally driven (for a review of the special fiscal issues experienced by transition economies see Buiter 1996). In conjunction, a commitment to subsequent reform appears to have been an important determinant of official flows. The access to capital markets that reforms have facilitated (at least in the most advanced reformers), however, has meant that official financing was quickly substituted by private capital flows (even though successful reformers usually still rely on official flows as contingent support).

\subsection{Dealing with Capital Flows: The Policy Framework}

As noted, countries improved the framework for capital flows largely through sustained structural reform efforts, involving liberalization, priva- 
tization, decentralization, stabilization, and institutional changes. Capital inflows have in general rewarded successful reforms and good policies by helping to finance investment needs and, in the case of FDI, by helping to improve productivity and access to foreign markets - thus helping to foster the further integration of transition economies into the global economy. While the benefits are clear, however, the crises in Mexico and Asia suggest that rapid surges of - particularly short-term - capital flows over a short time span can also pose difficulties to macroeconomic and financial sector management.

In CEE and FSU, only a few countries - and only recently-needed to deal with the potentially adverse effects of large capital inflows. There has consequently, in general, been little need for the responses traditionally employed when countries have faced large capital inflows (i.e., sterilization, exchange rate management, capital controls, prudential measures, capital outflow liberalization, and fiscal restraint; see further Corbo and Hernandez 1996). To illustrate policy responses to recent surges of capital inflows, we focus on the experiences of the Czech Republic, Poland, Estonia, Hungary, and Russia.

\subsubsection{The Czech Republic}

Following the initial transition years, when capital inflows were largely dominated by official sources, private capital flows became important. ${ }^{9}$ After averaging around $\$ 2.5$ billion annually in 1993-94 (over 80 percent of which was private finance), capital inflows rose in 1995 to $\$ 7.7$ billion, before declining to about $\$ 4$ billion in 1996 . These large private capital inflows were strongly driven by Czech reforms-including the restructuring needs that followed large-scale privatization, the gradual liberalization of its current and capital accounts starting in 1991, its overall conservative fiscal policy (with on average a fiscal deficit close to zero in 1993-96), and a relatively stable foreign exchange rate combined with a high differential between Czech and foreign interest rates. Expectations of exchange rate appreciation were also an important factor, particularly in motivating portfolio inflows. Strong debt flows occurred in 1995-96, as bank and enterprises borrowed abroad heavily, reflecting the high interest differentials. Also, FDI trebled between 1994 and 1995, to about \$2.5 billion, explained largely by the sale of 27 percent of the equity of the Czech telephone company to a Dutch-led consortium (collecting a record $\$ 1.45$ billion in a single transaction).

As the exchange rate was fixed with respect to the deutsche mark (DM), the Czech Republic's largest trading partner, and inflation remained at around 10 percent the real exchange rate appreciated sharply during the 199496 period. Increases in inflation from wage pressures and slow pro-

9. This subsection is based in part on Klacek (1997). 
ductivity growth led to large increases in relative unit labor costs. A current account surplus in 1993 (equivalent to 2 percent of GDP) turned into a large deficit in 1997 (equivalent to 7 percent of GDP) and a significant export slowdown followed in 1996 and 1997. Since 1996, net capital inflows have declined sharply and the scarcity of foreign financing has been reflected in an increasing interest rate spread between the Prague InterBank Offering Rate (PRIBOR) and LIBOR; the spread rose from around 5 percent in March 1995 to almost 9 percent in early 1997.

The Czech Republic was initially reluctant to interfere with the large capital flows, consistent with its laissez-faire approach to economic management. As capital flows grew in 1995, however, the Czech government started with large sterilized interventions through open market operations, higher reserve requirements on demand and time deposits, and depositing privatization receipts with the central bank. This resulted in a further real appreciation and rise in interest rates. While the adverse monetary impact of reserve growth was partially avoided, high capital inflows continued, motivated increasingly by higher interest rates. The movements in the interest spread followed the capital flow cycle: During the first phase, "exogenous" capital flows driven by sustained reforms lowered the interest differential, but as the current account moved into deficit and the pace of reforms slowed down, higher interest rates were necessary to maintain the "flow of capital."

In March 1996, the government tried to deter speculative capital flows by widening the exchange rate band from 1.5 percent to 15 percent - that is, \pm 7.5 percent around the central parity. The measure had the desired effect of slowing down and in fact reversing short-term capital inflows. The government did not, however, tighten its fiscal stance or introduce capital controls. Following a banking sector crisis in early 1997 (in which several larger banks were liquidated), and following the growing perception that enterprise and bank restructuring has been advanced less than initially thought, there was a speculative run against the Czech koruna. This led to a sharp downward correction in stock market prices and sizable exchange rate devaluation, followed by significant capital outflows in mid-1997. The government was subsequently forced to tighten fiscal policy and strengthen regulation and supervision of its banking system and capital markets.

\subsubsection{Poland}

Official inflows played an important role during the first years of the transition, particularly in financing government deficits. ${ }^{10}$ During the whole 1990-96 period, however, net flows of long-term official credits were close to zero as Poland repaid significant sums. Private capital flows to

10. This subsection is based in part on Durjasz and Kokoszczynski (1997). 
Poland initially lagged behind those to the Czech Republic and Hungary; however, a sizable increase occurred following its commercial debt and debt service reduction agreement in October 1994. The bulk of private capital inflows to Poland after 1994 took the form of FDI, which rose from about $\$ 1.8$ billion annually in 1993-94 to $\$ 6.6$ billion in 1997 . Poland became the largest recipient of FDI in the region on a cumulative basis over 1992 -96. Inflows of FDI to Poland were driven by Poland's structural reforms, the de facto zloty convertibility since 1991 (initially for current account transactions and later for most capital account transactions), moderate fiscal deficits, overall good macroeconomic performance (highest cumulative growth of the region over 1992-97), and favorable prospects for EU membership. Privatization of state enterprises can explain about 20 percent of FDI inflows - far less than in Hungary. Most valuable Polish companies have not been privatized yet (copper, telecommunications, energy, insurance, and several of the large banks). Portfolio inflows became significant in 1995, with purchases of treasury bills by foreigners reaching $\$ 1$ billion that year - encouraged by high yields and expectations of significant nominal zloty appreciation - and in 1997. In 1996-97, several banks and companies issued medium-term paper in the Eurobond market and benefited from low and declining spreads, reaching under one hundred basis points over equivalent U.S. treasuries in 1997.

Capital inflows and a current account surplus in 1995 were associated with strong monetary and credit expansion and with slow disinflation. A 20 percent real exchange rate appreciation in 1995-96 was followed by a deterioration of the current account balance equivalent to almost 8 percentage pqints of GDP over 1996-97. The government responded to the above concerns with a more flexible exchange rate regime, sterilized interventions, and a tightened monetary and fiscal policy. Poland did not rely on explicit capital controls to manage adverse capital flows. A permission from the central bank for foreign credits and loans with a repayment period of less than twelve months (for services other than commodity circulation and individuals' services) appears to have had no significant effect on the structure of flows. Similar requirements for longer-term loans and credits were lifted as a result of Organization for Economic Cooperation and Development (OECD) membership negotiations.

The greatest concern in the second half of 1994 and 1995 was the impact on inflation of rapid foreign reserve growth. The largest source of foreign reserve accumulation in 1994 and 1995 was "net unclassified transactions" of the current account $-\$ 9.6$ billion between 1995 and the first quarter of 1996. These refer mostly to flows on account of cross-border trade and tourism, motivated by high price differentials between Poland and Germany, on one hand, and Poland and countries to the east on the other. Other substantial (albeit smaller) sources of reserve growth were portfolio 
and FDI inflows. The government responded with a combination of sterilized interventions and a more flexible exchange rate policy regime. Open market operations trebled between the first half of 1994 and the second half of 1995. The widely spread perception that the exchange rate was undervalued led to the creation of a wide exchange rate band of \pm 7 percent around the central parity in May 1995. The exchange rate quickly appreciated to the top of the band and by years end the band itself was appreciated. Following a slowdown in foreign exchange reserve accumulation since the second quarter of 1996-also facilitated by the liberalization of purchases of foreign assets such as real estate and portfolio investments by residents (an OECD membership requirement) - the central bank was able to reduce its sterilization activities and maintain the exchange rate policy adopted during 1995 . The above policies were also supported by a deliberate commitment to lower interest rates as a means to discourage portfolio flows driven by high interest rate differentials. The period did see, though, a rapid surge in domestic credit associated with a hike in domestic aggregate demand and a turnaround of the current account from a 4.6 percent of GDP surplus in 1995 to a deficit of 1 percent of GDP in 1996.

The biggest concern in 1997 was the further deterioration of the external current account. Monetary policy was sharply tightened starting early in 1997, with real interest rates in treasury bills and bonds rising from around 0 percent in previous years to about 10 percent during the year. To enhance the effectiveness of the monetary policy transmission mechanism, the central bank accepted deposits directly from the public - thus inducing some large state-owned banks to raise their deposit rates. With high domestic interest rates, there was a new surge of portfolio flows. To reduce these inflows, the government responded by eliminating altogether intraband exchange rate interventions, thus effectively raising the exchange rate uncertainty faced by short-term speculative capital flows, renewing sterilization activity, and imposing a tighter than anticipated fiscal policy. By October, there was a deceleration of credit growth and the current account balance ended the year with a 3.2 percent of GDP deficit, substantially less than had earlier been anticipated.

\subsubsection{Estonia}

Capital inflows to Estonia were dominated by domestic factors, including the introduction of domestic currency linked through a currency board system to the DM, attractive interest rate differentials, structural reforms (especially trade and banking sector reform), and an active privatization program. Capital inflows (beginning in 1993) preceded the economic recovery-following four years of rapid contraction, output growth only resumed in 1995. Capital inflows were initially dominated by FDI inflows. Since mid-1995, however, there has been a relative decline of FDI in over- 
all capital flows and a surge in domestic banks' access to international capital markets. The counterpart of the latter development was a rapid surge in private domestic credit. Driven by private aggregate demand (fiscal deficits averaged 0.5 percent of GDP during the $1993-96$ period), the current account balance declined from a surplus in 1993 to a deficit of over 10 percent of GDP in 1996 and 13 percent in 1997. Under the currency board regime, the central bank's monetary interventions have been limited to buying and selling foreign exchange to preserve the parity with the DM. Since there has been no intervention through open market operations, base money growth has been driven by the demand for domestic assets. Strong demand for domestic assets led to high growth of monetary base, broad money (including foreign exchange deposits), as well as credit between 1992 and 1997. Estonia did not resort to capital controls or to sterilization.

The rapid growth of domestic credit, the declining share of FDI in capital inflows, the high current account deficit, and the turmoil in Asia since mid-1997, however, prompted the government to tighten banking sector prudential regulations and supervision in late 1997. The latter was aimed at curbing fast credit growth and, only indirectly, at curbing portfolio inflows (since banks were funding domestic credit with Eurobond issues). The creation of a stabilization fund - whereby budget surpluses and public sector deposits were invested in foreign assets abroad - and a number of other measures aimed at tightening monetary policy and regulations were announced in early October 1997. These other measures included raising the capital adequacy ratio from 8 percent to 10 percent, curbing local government's borrowing, extending reserve requirements for the banks to include net borrowing from abroad, and increasing the daily liquidity requirement for banks.

The announcement of these measures, combined with some indications from the government that it would remove public sector deposits from commercial banks to create the stabilization fund, and previously unanticipated delays in the funding abroad of several domestic banks, led to a liquidity crisis in the banking sector on 20 October 1997. Interest rates jumped over three hundred basis points and between 20 October and the end of November the stock market price index lost over 60 percent of its value. To restore confidence, the central bank decided to bring forward the implementation of the previously announced measures and announced new measures to tighten banking regulations, including a further increase in capital adequacy requirements to 12 percent-to be implemented at a later (unspecified) stage - and increases in the liquidity ratios of banks. The firm stance of banking regulators and the tightening of fiscal policy were conducive to a significant slowdown of credit growth and to improved liquidity in financial markets. 


\subsubsection{Hungary}

As a reward for its early reform efforts and continuous servicing of its foreign debt, Hungary received large capital inflows (including FDI) from the early 1990s on. ${ }^{11}$ Lack of fiscal discipline in 1993-94, however, led to a large surge in its current account deficit, reaching almost 10 percent of GDP in 1994, and created an unsustainable situation. The foreign exchange crisis in 1994 led to an economic downturn, and large debt financing to the public sector was necessary. Following fiscal adjustment and a devaluation in early 1995, there was a new surge in FDI closely linked to an ambitious privatization program (including the privatization of banks and some utilities). A sharp fiscal adjustment along with an intensification of structural reforms led to a rapid contraction in the current account deficit. Capital inflows declined as the path of fast privatization could not be sustained after 1995 .

Sterilized intervention was extensively pursued during the periods in which capital inflows threatened the monetary program. To a lesser extent, capital account liberalization also helped as it led to capital outflows. Exchange rate flexibility - that is, a devaluation - was used when capital outflow pressures dominated (1994-95). The sharp fiscal adjustment and monetary tightening subsequently helped to keep the current account deficit under control. Strong productivity growth (supported by structural reforms)--unit labor costs declined sharply-has been another key factor keeping the current account to manageable proportions.

\subsubsection{Russia ,}

Capital flows to and from Russia were characterized by large official inflows (on average $\$ 3.5$ billion during 1993-96), very large capital outflows or "capital flight" (errors and omissions in the balance of payments averaged $\$ 8$ billion in 1995-96), and since 1996 a surge in portfolio inflows, mostly in the form of purchases of treasury bills (GKO). The surge in both official and portfolio flows was closely linked with the large financing requirements of the budget -8.1 percent of GDP on average during 1993-97- and since 1996 with the government's strategy to increase the share of foreign financing of fiscal deficits as a way of reducing domestic financial and inflationary pressures. While the conditions attached to official flows has been supportive of ongoing reform efforts in the country, legal uncertainties, weak institutions, criminality, and limited opportunities for foreigners to participate in privatizations may explain why FDI has been relatively (to GDP) low. FDI averaged $\$ 600$ million in 1993-94 and $\$ 1.9$ billion in 1995-96. However, further increases are anticipated over the coming years as a result of reforms conducive to improving the 
business environment for foreign investors (e.g., faster privatization, improvements to the collateral system, land and tax reform, changes to the bankruptcy law, improved transparency in the accounts of state enterprises, and national treatment for foreign investors).

The scale of capital outflows (to the extent that they result from tax avoidance or evasion) in part explains the difficulties that the government faces in reducing its deficit. Capital outflows may also help explain why the sharp tightening of monetary policy in 1996 induced a strong rise in portfolio inflows (as Russians reinvested their money back into the country). Inflation has fallen substantially from 131 percent in 1995 to 21.8 percent in 1996 and to 11 percent in 1997. Interest rate declines lagged behind, however, with the average treasury bill rate falling from 176 percent in 1995 to 102 percent in 1996 and 33 percent in 1997. The resulting high real interest rates, combined with the sharp real appreciation of the currency in 1995 and 1996, have been key motives behind the surge in portfolio flows targeting fixed income instruments. Portfolio investors, mostly over two hundred foreign investment funds, primarily purchased treasury bills, with purchases in April 1997 peaking at \$2 billion. As real interest rates declined in 1997, investors have been increasingly targeting traded shares of Russian enterprises: In early 1997, they owned about onethird of such shares, or about $\$ 3$ billion. Unlike other large capitalimporting countries in the region, Russia did not pursue deliberate policies to slow down capital inflows. However, the exchange rate flexibility conferred by its wide exchange rate band has presumably been some deterrent against short-term portfolio flows.

\subsection{Econometric Tests and Evaluation}

The above sections suggest that the reasons for the capital flows are largely the pursuit of economic reform. They also make clear that the factors influencing capital flows have differed by the types of capital flow. Furthermore, policy responses (e.g., degree of sterilization, liberalization, or imposition of capital controls) have also differed by the degree and type of capital flows. To make these relationships more precise and to study the separate effects of some of these factors we provide some regression results in this section.

The main aim of the regressions is to try to explain the magnitude of the various types of capital flows for individual countries. Common with the existing literature (e.g., Calvo, Leiderman, and Reinhart 1993; Chuhan, Claessens, and Mamingi 1998; Hernandez and Rudolph 1995; Taylor and Sarnio 1997; see Montiel and Reinhart 1997 for a review of this literature), we distinguish two groups of explanatory variables: international factors ("push factors") and domestic factors ("pull factors"). Push factors are conditions in global capital markets that influence the supply of 
capital and are outside the control of a particular recipient country. Pull factors are country-specific factors and conditions influencing the interest of foreign capital of investing in that particular country. Some of these factors are under the control of the country, some are initial conditions, and others are outcomes which are in part influenced by capital flows themselves.

For the group of pull factors, we use the U.S.-dollar, six-month LIBOR interest rate and the economic growth in OECD countries. We expect that declines in world interest rates will have a positive effect on capital flows to CEE and FSU, as that will make the rate of return on investing in these countries higher relative to other alternatives. The effect of an increase in OECD growth rate is less obvious. On one hand, it will likely be associated with a rise in the rate of return on investment in OECD countries, thus reducing the attractiveness of investing in transition economies. On the other hand, higher growth may raise the supply of savings in OECD countries, thus stimulating capital flows.

The group of pull factors is divided into policy factors: "reform efforts," initial conditions, and "outcomes." Obviously, it is difficult to quantify the degree of policy reform a country has undertaken in absolute terms. The very similar starting position of most of the transition economies-controlled prices, little private sector activity, limited institutional development, and so forth-makes it somewhat easier to quantify at least the relative degree of policy reform in CEE and FSU. We use the liberalization index from De Melo, Gelb, and Denizer (1996) to rank countries in their relative reform efforts. This index, an indicator between 0 and 1 , is available for each country and for each year and aims to measure how far the country has progressed in liberalizing prices, trade, and private sector activities, including privatization. The initial conditions and outcomes variables are more difficult to separate, as capital flows are likely to interact with and affect current outcomes, which then become initial conditions for subsequent capital flows. We use the country's GDP growth rate, inflation, fiscal balance, private saving, and, as a credit worthiness indicator, the change in the country's reserves. We lag the change in the country's reserves and the two saving variables by one period to avoid possible simultaneity (as the sum of private, public, and foreign saving adds up to the change in reserves). In addition, we also use a dummy for the ten CEE countries likely to become EU members. ${ }^{12}$

We focus separately on factors that have likely influenced short-term private capital flows ("arbitrage factors"). In particular, we use the ex-

12. We use the following ten countries that have been identified by the EU as candidates: the Czech Republic, Poland, Hungary, Slovenia, Estonia, Romania, Bulgaria, the Slovak Republic, Lithuania, and Latvia. The first five have recently started negotiations with the EU; we set the dummy equal to 2 for these countries. The dummy is set to 1 for the other five countries, and to 0 for all other countries. 
change rate adjusted rate of return on holding domestic assets (i.e., the nominal domestic interest rates ${ }^{13}$ minus the rate of change in the local currency/dollar exchange rate) minus the U.S.-dollar interest rate. We also investigate the relationship between different types of capital flows and domestic credit growth, as important reinforcing effects for other developing countries have been found between private capital flows and the rate of domestic credit expansion. Depending on the quality of financial intermediation, these reinforcing effects can lead to subsequent problems, as has been found for East Asian countries (see Alba et al. 1999).

We perform regressions for seven different classifications of capital flows, focusing mainly on the source of capital: total capital flows, official flows, all private flows, FDI, commercial debt flows, portfolio flows (bonds and equity), and short-term flows. We study both total flows as well as categories within these flows because there might be substitution between the various flows, ${ }^{14}$ both in a narrow sense (e.g., portfolio flows and FDI can be substituted in a particular transaction) as well as in a broader macroeconomic sense (e.g., large inflows of one kind can encourage or deter flows of another kind).

We run our regressions in an unbalanced panel setup using a sample of twenty-one countries for the years 1992-96. The panel is unbalanced as we do not have data for our independent variables for each year for each country and have private capital outflows figures for only a few countries. We also had to eliminate three countries (Azerbaijan, Turkmenistan, and Tajikistan) for lack of reliable data. All our dependent variables, U.S.dollar capital flows, are scaled by U.S.-dollar GNP based on the Atlas method of the World Bank - which uses the moving average of the exchange rate over three years - to convert local currency GNP to U.S.dollar GNP. This way we smooth out the effect of large real exchange rate movements.

We have the option of estimating the regression model with individual effects or with a common constant term. The first, the fixed effects model, assumes that differences across the countries can be captured in differences in the constant term. The other option is to use ordinary least squares and estimate the regression model assuming that the constant term is the same across countries. To determine which type of estimation was most appropriate, we conducted $F$-tests for each regression, testing the hypothesis that the constant terms are all equal. The results suggested that for total, official, private, FDI, and commercial debt flows an estimation using a common constant, in addition to the EU-accession dummy

13. We use as much as possible the local treasury bill rate. For those countries where treasury bill rates were not available, we use the interbank interest rate or the bank lending rate.

14. We would like to thank Michael Dooley for reminding us of this possibility. 
variable, will provide the most consistent and efficient estimators. For the remaining types of flows, portfolio flows and short-term debt flows, the fixed effects model was more appropriate.

We correct for heteroskedasticity in the error terms of the regressions. In particular, the size of the country has an effect on the relationships. We expect that this effect arises for several reasons. First, because of fixed costs of acquiring information, we expect that small countries exhibit a less clear relationship between explanatory variables and capital flows, as investors will expend fewer resources in analyzing small country characteristics. Second, the lumpiness of some of the flows, particularly FDI but also of official flows, may make for more noisy relationships of flows (when scaled by GDP) for smaller countries. Third, we expect smaller countries to be less economically diversified and more affected by external and internal shocks, thus again creating more noisy relationships. Fourth, available data are likely more problematic for small countries as their statistical systems are less well developed. Plotting the error terms against the size of the country confirms this type of heteroskedasticity. For these reasons we use the estimated cross-section residual variances as weights in the regressions.

In light of the discussion from the previous sections, we start with a benchmark regression for all seven categories of capital flows with the following explanatory variables: reform index, a dummy for EU accession (which takes the value of 2 for those five countries currently in negotiations, 1 for the other five countries, and 0 for all other countries), and the change in the level of foreign exchange reserves (with declines in reserves having a positive sign). As a second step we add single additional explanatory variables, thus keeping the total number of variables to four. Results for these seven regressions are presented in table 9.4.

We find that the reform and reserves variables are significant explanatory variables of all categories of flows; the EU dummy is significant for two of the seven categories. Not surprisingly, we find that the effort in undertaking reform in a particular country is positively associated with all types of flows, except for official and portfolio flows. This suggests that reforms were important motivating factors for private capital flows. Reform effort also matters in determining official flows, but with a negative coefficient. This would suggest that official financing went to those countries that have reformed less. The correct interpretation, however, might be that official financing went to those countries that had achieved less reform initially, but that some conditionality was being applied in official financing. Reform efforts may then have increased following large official flows, and over time the official flows to those countries that had achieved more reform declined. This overall negative relationship for official flows thus reflects that they preceded reform efforts and fell off as reforms 


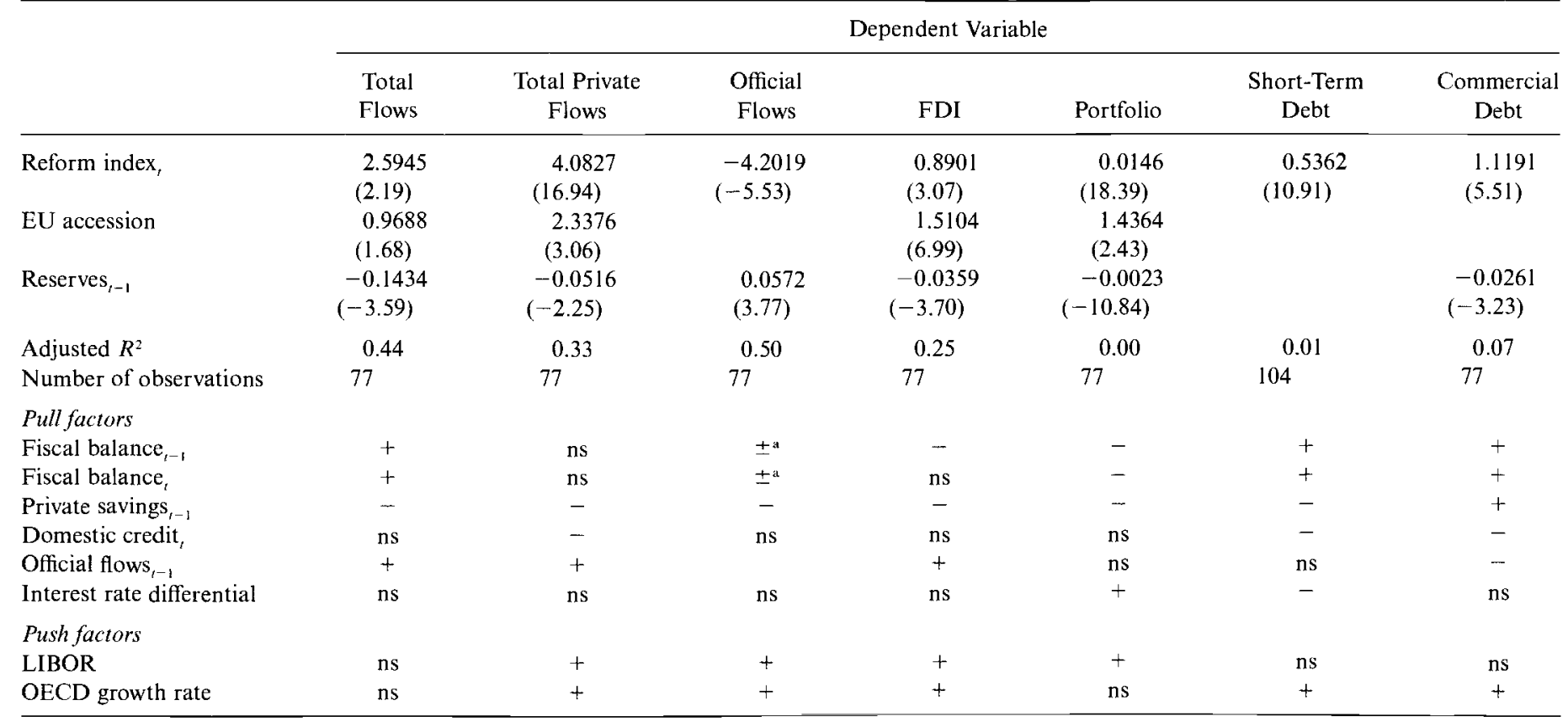

Notes: The estimation procedure is generalized least squares with cross section residual variances as weights. ns $=$ no significant; $+=$ positive significant; $-=$ negative significant. $t$-statistics are in parentheses.

${ }^{a}$ Due to a high correlation between reform index and fiscal balance $(0.83)$, the sign of the coefficient for fiscal balance becomes negative when reform index is dropped from the regression. 
progressed. ${ }^{15}$ This result suggests that a dynamic model of official capital flows and progress in liberalization is required. The negative sign for the reform variable in the case of portfolio flows likely reflects that a significant part of portfolio flows was directed toward the financing of fiscal deficits, which may have been larger in countries that reformed less.

For FDI, the dummy for EU accession is positively significant. It is likely that EU accession is most important for FDI as the prospects of increased integration with Western Europe has meant that both opportunities for favorable investments and overall credit worthiness increase in these countries more than in others.

The negative sign for the lagged change in reserves variable for most flows reflects the fact that increased credit worthiness of countries, that is, as they increased reserves, motivated further capital flows. The positive sign for the lagged changes in reserves variable for official flows reflects that, at least initially, official financing was made available on a financing needs basis: As reserves declined, more official financing was made available. Similarly for portfolio flows, much of which was directed to financing of fiscal deficits, financing need was an important determinant.

As mentioned, we added to this basic regression a number of additional variables, including each separately. Specifically, we included public sector balance, current as well as lagged one period (to avoid simultaneity between foreign and domestic savings), private savings (lagged one period), domestic credit growth, lagged official flows, and the interest differential. We also include the two push variables, LIBOR and OECD growth rates. Rather than presenting all the detailed regressions results, we simply present whether the particular additional variable was significant, and if so, with what sign (see table 9.4).

We find that fiscal surpluses, both contemporaneous and lagged, are positively related with about half of the different types of flows. This suggests that increased fiscal surpluses stimulate foreign savings through a credit worthiness effect. The negative coefficients for official flows show that official flows to the public sector have been associated with larger fiscal deficits (see also fig. 9.10 in section 9.3). The coefficient is also negative for portfolio flows, likely because countries with larger fiscal deficits receive more portfolio flows through foreign purchases of government bonds (particularly Russia). Lagged private saving has a negative coefficient for all flows except commercial debt flows. This suggests that there is some substitution between foreign and private saving, a general finding for developing countries (see Cohen 1993). The coefficients are small, however, so concerns about the sustainability of foreign flows, as they end up

15. A regression of reform on lagged official flows indeed confirms this relationship. Using a fixed-effect estimator, we find that the coefficient for lagged official flows is significantly positive and has a $t$-statistic of 2.74 . 
financing some share of consumption, may not be too serious. The positive sign for private saving in the commercial debt flows regression may reflect a credit worthiness effect.

Domestic credit growth is significantly negative in the case of total private flows, short-term flows, and commercial debt flows. This suggests that the typical reinforcing effect of capital flows on domestic credit growth is not prevalent in these countries. This may be because of the poor institutional development of the domestic financial sector. The negative sign may also reflect that the enterprise restructuring required in these countries was often achieved through tight (hard) budget constraints. Countries with less growth in domestic credit may have been more successful with enterprise restructuring; they thus were more likely candidates for private capital flows because their credit worthiness in general increased and because a greater fraction of domestic firms were restructured and thus of interest to foreign investors.

Lagged official flows have a positive effect on almost all types of capital flows. Since the regression already controls for the reform effort of the particular country, which thus captures the degree to which official lenders may have been successful in their reform conditionality, there is an independent effect of past official lending on private capital flows. This may be because official lending acted as an important signal to private creditors regarding the commitment of the country to undertake further reforms.

The interest differential variable is significant for only two of the types of capital flows: portfolio flows and short-term flows. Only for portfolio flows does it have the expected positive sign, while for short-term flows the sign is negative. This suggests that, once one controls for a few basic variables, capital flows at large have not been motivated by arbitrage conditions.

Push factors appear to play a role in motivating capital flows, but with the opposite sign from what is commonly found. Specifically, increases in international interest rates are associated with increased capital flows. And higher OECD growth rates also increase capital flows. This contradictory finding raises some questions of its own, but at least it does not suggest that capital flows to these countries are at risk for increases in international interest rates and OECD growth. It may rather be that increases in OECD growth enhance the supply of foreign savings available for these countries.

Table 9.5 provides the regression results for the specification chosen for each type of capital flow. The explanatory variables were chosen after some experimentation to achieve a reasonable overall fit for the regression, within constraints of data availability.

In the case of total flows, reform efforts, EU accession, and changes in reserves have the same sign as before. Additional significant explanatory variables are the lagged fiscal balance and lagged official capital flows, both with a positive coefficient. 


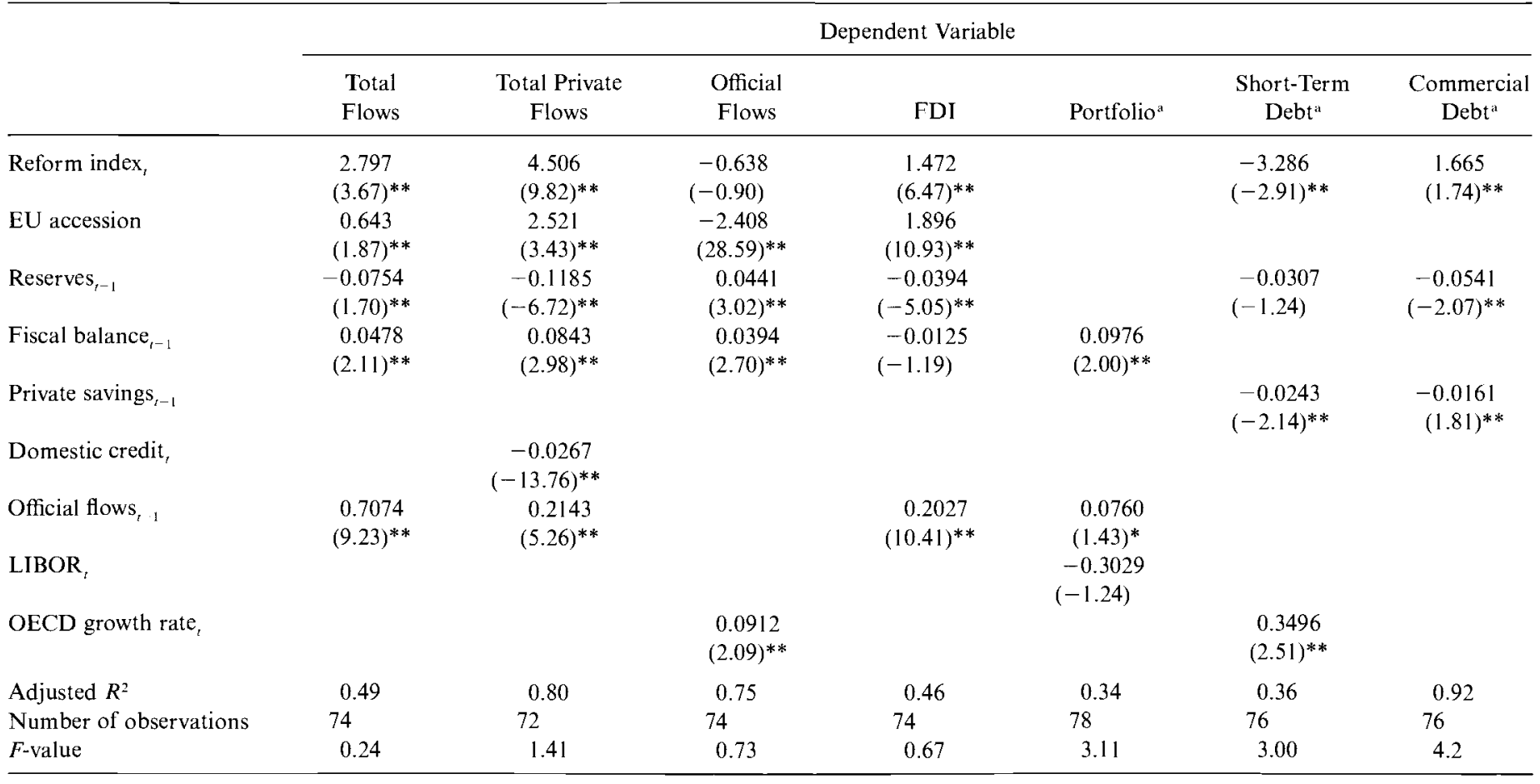

${ }^{a}$ Fixed effects model estimation was used for these types of flows, given that the hypothesis that the country effects are the same was rejected (see $F$-values).

* Significant at the 10 percent level.

**Significant at the 5 percent level. 
Total private capital flows depend strongly on reform efforts. We again find a positive coefficient for those countries with possible accession to the EU and a negative relationship with the lagged change in foreign exchange reserves, which suggests that credit worthiness is an important factor. Higher (lagged) fiscal savings tends to raise private flows, suggesting that credit worthiness and reform perceptions are influenced positively by reduced fiscal deficits. More generally, the positive relationship between private capital flows and fiscal saving suggests a complementarity between public and foreign saving. We also find a positive coefficient for lagged official flows, a possible confirmation of the signal from past official lending on future reforms and credit worthiness. Private capital flows are negatively related to domestic credit growth, suggesting that contractions in credit growth may have served as a signal of reform.

In the case of official flows, the results show that reform efforts again enter with a negative (but insignificant) coefficient. Countries that are candidates to become members of the EU have received less official financing, suggesting that, because they received more private financing and progressed further in reforms, they were in less need of official financing. This need for financing is again confirmed in the positive coefficient for the reserve variable, indicating that declines in foreign exchange reserves are associated with more official financing. Lagged fiscal surpluses have a positive relationship with official flows, suggesting official flows were made conditional on past fiscal efforts. The high correlation between fiscal surpluses and reform efforts, however, implies that when the reform variable is removed, the sign of the fiscal surplus variable becomes negative, that is, there is collinearity between regressors. The interpretation in this latter case is more straightforward: Lower fiscal surpluses (higher deficits) are associated with larger official flows. The coefficient for OECD growth rate is significantly positive, suggesting that the supply of official saving may have been a positive function of the business cycle in industrial countries.

As we showed above, FDI is the most important private capital flow for most countries. In this specification, FDI is dependent as before on the three major independent variables: reform efforts, EU accession, and reserve changes. Not surprisingly, as for all private capital flows, FDI is greatly influenced by reform efforts, as the $t$-statistic for the reform index is large. Lankes and Stern (1999) and Martin and Selowsky (1997) had already noted this. Lagged official flows are positively significant, suggesting again a signaling function of official flows.

Portfolio flows appear to be driven by a number of factors, some of which are collinear, thus leading to mostly insignificant coefficients when many variables are included. The best regression result is then also not very informative. Fiscal balance (lagged one period) now appears to increase portfolio flows, a finding different from the earlier regression where the opposite coefficient was found. Interestingly, the interest rates differ- 
ential variable is not significant. As noted, not all of these relationships are robust to inclusion of other independent variables, in part likely because of the collinearity of the independent variables, but also because portfolio flows are relatively small and have occurred only in more recent years, thus leading to weaker relationships.

Lastly, we regressed the flow of short-term debt flows and commercial debt flows. As noted, short-term debt has become a large share of private capital flows in recent years for a number of countries. Private debt flows and short-term debt flows appear to be driven by the same factors, except for reform efforts. The degree of reform matters in a positive way for commercial debt flows and negatively for short-term debt flows. The negative sign for short-term flows, which differs from the results in table 9.4, could reflect that lenders were less willing to extend long-term funds, and relatively more willing to extend short-term funds, to countries that had undertaken less reform. Increases in reserves lead to larger commercial debt and short-term flows (the latter is insignificant, however). This suggests that credit worthiness also matters for these flows. Private debt flows appear to be substitutes for domestic private saving as the coefficients are negative. Finally, OECD growth rates matter for short-term flows. We find no evidence of a push effect, as the coefficient for the LIBOR interest rates is insignificant; in other words, the decline in international interest rates has not stimulated commercial debt or short-term flows. Arbitrage factors, that is, the interest differential, do not appear to have a significant effect on short-term flows, which is somewhat surprising.

In short, the overall results indicate that flows are driven for most countries by fundamental reforms and credit worthiness. The possibility of EU accession has been an important determinant of private flows, especially FDI. For official flows, EU accession seems to have lowered the need for official flows. Increased fiscal saving has led to higher volumes for most flows while increased private saving has been associated with lower capital flows, suggesting some degree of substitutability between private and foreign saving. Official flows appear to have had an important signaling value for private capital flows. For no flows did high interest rate differentials (adjusted for exchange rate movements) appear to have mattered. Push effects are only found for commercial debt and short-term debt flows, with growth in OECD countries encouraging flows to the region.

\subsection{Conclusions and Forward-Looking Issues}

Capital flows to CEE and FSU have been increasing rapidly in recent years - a growth rate of 34 percent per year during 1991-97 but are still a small fraction of global capital flows to developing countries (about 18 percent in 1997). As structural reforms have progressed, the composition of flows has changed: Official flows have declined, and private capital flows 
have increased to account by 1997 for about 73 percent of total flows. Within private capital flows, FDI was the most important followed by portfolio flows. As the direct and spillover effects of FDI on human, technological, and physical capital accumulation are crucial for the rapid and effective integration of the transition economies to the world economy, this bodes well for these countries.

Perhaps more than in other developing countries, reform efforts have been the most important determinant of private flows, particularly of FDI. Other consistent determinants of private flows have been prospective EU membership - the ten countries that applied for EU membership attracted more private flows (and relied less on official flows) - and credit worthiness. Credit worthiness proxies such as increases in reserves, lower fiscal deficits, and greater past official flows were mostly positively correlated with greater private flows. The association between declines in private saving and higher private debt flows, however, causes some concern.

One key policy implication is that the sustainability of capital flows is associated with the sustainability of reform efforts. The consistency and continuity of structural reforms-particularly those that are conducive to EU integration and improved credit worthiness-can influence the source (official versus private) as well as the type of private capital flow (e.g., the reform's impact on FDI flows is positive while the impact on short-term debt flows is negative). This, in turn, implies that reform efforts matter not just for the level of capital flows, but also for the maturity and potential volatility of flows.

The shift from debt-creating flows to the public sector in the 1980 s to non-debt-ereating flows to the private sector in the 1990s also has implications for the efficiency of resource and risk allocation. For one, private recipients of capital have better incentives to allocate capital into higher return projects. The shift to non-debt-creating flows, in turn, implies a better risk-sharing arrangement (of fixed-term foreign currency obligations) vis-à-vis foreign investors.

Another feature of capital flows to the region has been the increase in the share of short-term debt and portfolio flows since 1993. The concentration of these potentially more volatile short-term flows in 1993-96 in a few countries raises questions about sustainability of capital flows and vulnerability to international shocks in these economies. For the majority of countries in the region, however, the absolute and relative level of shortterm foreign obligations is small compared to the size of their economies as well as compared to the high levels of their foreign exchange reserves.

So far, only a few countries have had to deal with episodes of overheating. Looking forward, it is likely that more countries will have to deal with the constraints that the level and structure of external liabilities may pose on macroeconomic and financial policy. The experiences in the region confirm global lessons: Dealing with overheating requires determined, 
countercyclical fiscal policies (to counter the potential overheating caused by large capital inflows) and better supervision and tighter prudential regulations on the financial sector (such as raising reserve requirements on foreign borrowings). Sterilization of inflows and exchange rate flexibility can be effective in the short run to reduce large capital inflows and their impact, but are usually constrained by quasi-fiscal implications (in the case of sterilization) and by competitive pressures (in the case of exchange rate flexibility), for example, from exporters.

Looking forward, our analysis raises two other issues of potential concern: fiscal sustainability and the quality of domestic financial intermediation. As already pointed out by Buiter (1996), some countries appear to face fiscal sustainability issues, especially when including public offbalance-sheet activities. Buiter highlights the combination of high domestic real interest rates and the rapid buildup of domestic liabilities, both explicit and implicit through the banking systems. We find evidence here of potential problems with fiscal sustainability from an external perspective as capital flows are sometimes associated with larger fiscal deficits and high interest rates, a combination that is seldom sustainable. For transition economies, potential or hidden liabilities in state-owned enterprises (e.g., resulting from poor governance), in weak financial institutions, and in insolvent social security and health systems thus need to be carefully monitored. The risk otherwise may be a sudden decline in perceived credit worthiness, leading to a sharp contraction or reversal of private flows.

A second concern relates to the quality of domestic intermediation of (external and domestic) funds. The quality of the financial sectors in transition economies is still weak. Cross-country indicators of quality of domestic intermediation (such as those in the annual reports of the European Bank for Reconstruction and Development [EBRD]) suggest for some countries a limited institutional development and a weak financial condition, including large amounts of nonperforming loans. While we did not find that the quality of financial intermediation itself was an important explanatory factor of capital flows, it would be useful to further analyze the issue of banking fragility, also as that has been an issue in other emerging markets and likely a key policy area. A particularly useful area of research could be to investigate the interactions between high domestic credit growth, weak domestic financial intermediation, and the type of capital flows.

\section{References}

Alba, Pedro, Amar Bhattacharya, Stijn Claessens, Swati Ghosh, and Leonardo Hernandez. 1999. The role of macro-economic and financial sector linkages in 
East Asia's financial crisis. In The Asian financial crisis: Cause, contagion, and consequences, ed. P. Agenor, M. Miller, D. Vines, and A. Weber. Cambridge: Cambridge University Press.

Buiter, Willem H. 1996. Aspects of fiscal performance in some transition economies under fund-supported programmes. CEPR Working Paper no. 1535. London: Centre for Economic Policy Research, December.

Calvo, Guillermo, Leonardo Leiderman, and Carmen Reinhart. 1993. Capital inflows and the real exchange rate appreciation in Latin America: The role of external factors. IMF Staff Papers 40, no. 1 (March): 108-51.

Chuhan, Punam, Stijn Claessens, and Nlandu Mamingi. 1998. Equity and bond flows to Latin America and Asia: The role of global and country factors. Journal of Development Economics 55:439-63.

Claessens, Stijn, and Wafa Abdelati. 1996. Enterprise performance and adjustment in Romania. Washington, D.C.: World Bank, May. Mimeo.

Claessens, Stijn, and R. Kyle Peters Jr. 1997. State enterprise performance and soft budget constraints: The case of Bulgaria. Economics of Transition 5 (2): 302-22.

Cohen, Daniel. 1993. Low investment and large LDC debt in the 1980s. American Economic Review 83 (June): 437-49.

Corbo, Vittorio, and Leonardo Hernandez. 1996. Macroeconomic adjustment to capital flows: Lessons from recent Latin America and East Asian experiences. World Bank Research Observer 11, no. 1 (February): 61-84.

De Melo, Martha, and Cevdet Denizer. 1997. Monetary policy during transition: An overview. World Bank Working Paper no. 1706. Washington, D.C.: World Bank, January.

De Melo, Martha, Alan Gelb, and Cevdet Denizer. 1996. Patterns of transition from plan to market. World Bank Economic Review 10, no. 3 (September): $397-424$.

Durjasz, Pawel, and Ryszard Kokoszczynski. 1997. Financial inflows to Poland. Paper presented at the workshop Financial Inflows to Transition Economies, organized by the International Institute for Applied Systems Analysis, Laxenburg, Austria, 9-10 May.

Easterly, William, and Paulo Viera da Cunha. 1994. Financing the storm: Macroeconomic crisis in Russia. Economics of Transition 2 (December): 443-65.

Hernandez, Leonardo, and Heinz Rudolph. 1995. Sustainability of private capital flows to developing countries: Is general reversal likely? Policy Research and External Affairs Working Paper no. 1518. Washington, D.C.: World Bank, October.

Klacek, Jan. 1997. From attracting foreign capital to managing capital flows: The Czech case. Paper presented at the workshop Financial Inflows to Transition Economies, organized by the International Institute for Applied Systems Analysis, Laxenburg, Austria, 9-10 May.

Lankes, Hans Peter, and Nicholas Stern. 1999. Capital flows to Eastern Europe and the former Soviet Union. In International capital flows, ed. Martin Feldstein, 57-97. Chicago: University of Chicago Press.

Martin, Ricardo, and Marcelo Selowsky. 1997. Policy performance and output growth in the transition economies. American Economic Review Papers and Proceedings 87 , no. 2 (May): $349-53$.

Montiel, Peter, and Carmen Reinhart. 1997. The dynamics of capital movements to emerging economies during the 1990s. Williams College and University of Maryland, July, prepared for the UNU/WIDER project Short-Term Capital Movements and Balance of Payments Crises. Mimeo.

Oblath, Gabor. 1997. Recent capital inflows to Hungary and policy responses. Paper presented at the workshop Financial Inflows to Transition Economies, 
organized by the International Institute for Applied Systems Analysis, Laxenburg, Austria, 9-10 May.

Sobol, Dorothy M. 1996. Central and Eastern Europe: Financial markets and private capital flows. Working Paper no. 9626. New York: Federal Reserve Bank of New York, August.

Taylor, Mark P., and Lucio Sarnio. 1997. Capital flows to developing countries: Long- and short-term determinants. World Bank Economic Review 11, no. 3 (September): 451-70.

World Bank. 1992. World debt tables, 1991/2. Washington, D.C.: World Bank. 1998. Global development finance. Washington, D.C.: World Bank, March.

\section{Comment Michael P. Dooley}

This paper provides a valuable review and evaluation of private capital flows into formerly planned economies. It is particularly useful because it provides a factual basis for comparing these countries' experiences with those of other emerging markets. The paper was completed before the crisis in Russia but cautions readers that Russia and the other formerly planned economies are vulnerable to a reversal of capital inflows.

Perhaps the most striking aspect of this paper is the recognition that recorded private capital inflows to Russia and some of the other countries studied were completely and simultaneously matched by unrecorded private capital outflows. A simple comparison of current account balances, official lending, and reserve accumulation leads to this conclusion.

This, in turn, poses a difficult problem for the econometric work reported and its interpretation. The main result is that reform and reserve accumulation seem to predict recorded capital inflows. But why would these same factors tend to generate unrecorded private capital outflows? The answer probably lies in a more structural story about the incentives faced by residents and nonresidents and governments that lead to cross-hauling of financial claims and liabilities.

In a relatively simple model with a representative private sector investor and a government, we can see how official capital outflows in the form of reserve accumulation might be systematically matched by private capital inflows. The familiar story is that sterilized exchange market intervention designed to resist currency appreciation generates a pattern of interest rate differentials and exchange rate expectations that induce private investors to arbitrage excess returns in the home markets. As the authors point out, this seems to play some role in the pattern of capital inflows observed in several of the countries studied.

But on top of this model we must also consider at least two sets of

Michael P. Dooley is professor of economics at the University of California, Santa Cruz, and a research associate of the National Bureau of Economic Research. 